\title{
Fat and Protein Combat Triggers Immunological Weapons of Innate and Adaptive Immune Systems to Launch Neuroinflammation in Parkinson's Disease
}

\author{
Shelby Loraine Hatton ${ }^{1}$ and Manoj Kumar Pandey ${ }^{1,2, *}$ \\ 1 Cincinnati Children's Hospital Medical Center, Division of Human Genetics, 3333 Burnet Avenue, \\ Cincinnati, OH 45229, USA; hattons1@mail.uc.edu \\ 2 Department of Pediatrics, Division of Human Genetics, College of Medicine, University of Cincinnati, \\ 3333 Burnet Avenue, Cincinnati, OH 45229, USA \\ * Correspondence: manoj.pandey@cchmc.org
}

Citation: Hatton, S.L.; Pandey, M.K Fat and Protein Combat Triggers Immunological Weapons of Innate and Adaptive Immune Systems to Launch Neuroinflammation in Parkinson's Disease. Int. J. Mol. Sci. 2022, 23, 1089. https://doi.org/ 10.3390/ijms23031089

Academic Editor: Botond Penke

Received: 31 December 2021

Accepted: 14 January 2022

Published: 19 January 2022

Publisher's Note: MDPI stays neutral with regard to jurisdictional claims in published maps and institutional affiliations.

Copyright: (C) 2022 by the authors. Licensee MDPI, Basel, Switzerland. This article is an open access article distributed under the terms and conditions of the Creative Commons Attribution (CC BY) license (https:// creativecommons.org/licenses/by/ $4.0 /)$.

\begin{abstract}
Parkinson's disease (PD) is the second-most common neurodegenerative disease in the world, affecting up to 10 million people. This disease mainly happens due to the loss of dopaminergic neurons accountable for memory and motor function. Partial glucocerebrosidase enzyme deficiency and the resultant excess accumulation of glycosphingolipids and alpha-synuclein ( $\alpha$-syn) aggregation have been linked to predominant risk factors that lead to neurodegeneration and memory and motor defects in PD, with known and unknown causes. An increasing body of evidence uncovers the role of several other lipids and their association with $\alpha$-syn aggregation, which activates the innate and adaptive immune system and sparks brain inflammation in PD. Here, we review the emerging role of a number of lipids, i.e., triglyceride (TG), diglycerides (DG), glycerophosphoethanolamines (GPE), polyunsaturated fatty acids (PUFA), sphingolipids, gangliosides, glycerophospholipids (GPL), and cholesterols, and their connection with $\alpha$-syn aggregation as well as the induction of innate and adaptive immune reactions that trigger neuroinflammation in PD.
\end{abstract}

Keywords: lipid; alpha-synucleinopathy; inflammation

\section{Introduction}

Parkinson's Disease (PD) is an age-related neurodegenerative disease that affects $\sim 1-2 / 1000$ people [1]. The prevalence of PD in the U.S. is $~ 572 / 100,000$ people above the age of 45. Based on U.S. Census Bureau population records in 2010, the number of cases for those over the age of 45 in 2010 was 680,000, which is expected to rise to 1,238,000 cases by 2030 [2]. PD mainly happens due to loss of dopaminergic neurons in a very specific region of the brain-termed the substantia nigra pars compacta-specifically due to Lewy body formation, overactivation of the immune system, microgliosis, and oxidative stress [3-14]. These proinflammatory environments influence disease processing and the development of the motor (e.g., tremor, rigidity, bradykinesia/akinesia, and postural instability) [15-17] and non-motor symptoms, (e.g., changes in apathy, anhedonia, depression, cognitive dysfunction hallucinosis, and complex behavioral disorders) [17]. While 5-10\% of PD cases are familial and happen due to several genetic defects [18], 90-95\% of cases have unknown causes and are idiopathic in nature [19]. Glucocerebrosidase (GCase) deficiency and the resultant excess brain accumulation of glycosphingolipids, $\alpha$-synuclein ( $\alpha$-syn) aggregation, proinflammatory cytokine generation, and reactive oxygen species (ROS) production have been linked to PD with both known and unknown causes [20-31]. Several other lipids have also been shown to have a direct or indirect role in the induction of $\alpha$-syn aggregation and the massive generation of ROS and proinflammatory cytokines in PD [32-36]. $\alpha$-syn is a cytosolic protein, found mostly in the brain, that is encoded by the SNCA gene [37]. It was discovered along with $\beta$-syn and $\gamma$-syn in the presynaptic terminals of axons [38]. Normal 
$\alpha$-syn has been linked to the restriction of synaptic vesicle mobility, attenuation of synaptic vesicle recycling, stabilization of soluble N-ethylmaleimide-sensitive factor attachment protein receptor complexes via chaperone activity, and controlling neurotransmitter release [39-42]. However, the exact function of $\alpha$-syn remains largely unknown [43]. $\alpha$-syn at the monomeric level is defined as a soluble monomer with a disorganized confirmation [44]. $\alpha$-syn accumulates in the form of Lewy bodies (LBs) and Lewy neurites (LNs) in a group of neurodegenerative diseases collectively known as synucleinopathies, which comprise PD, dementia with Lewy bodies (DLB), and multiple system atrophy (MSA) $[45,46]$. LBs and LNs accumulate $\alpha$-syn and trigger its prion-like spreading [47,48]. Glycophosphatidylinositol (GPI) anchors, phosphatidylethanolamine (PE), gangliosides, and several lipid-like molecules have been linked to the conversion of normal cellular protein to pathogenic forms of prion proteins [49-56]. Aggregated forms of $\alpha$-syn are able to recruit and seed the endogenous protein and initiate its spreading throughout the cells of the nervous system in animal and human models of synucleinopathies, aging, and and other brain diseases [57-67]. There is growing evidence indicating that abnormal $\alpha$-syn can spread to neighboring brain regions and cause aggregation of endogenous $\alpha$-syn in these regions as seeds, in a "prion-like" manner [68]. $\alpha$-syn has a high affinity to negatively charged lipids, and therefore its lipid-binding domain also interacts with platelet-activating factor, glycerophosphocholine (GPL), and lipid species with shorter hydrocarbon tails, which all show a link to $\alpha$-syn aggregation $[69,70]$. Furthermore, $\alpha$-syn gene (SNCA) defects also altered $\alpha$-syn lipid-binding domains, which suggests the importance of phospholipid membranes and monomeric $\alpha$-syn interactions [71]. At the monomeric level, several of the lipids, such as triglyceride (TG), diglycerides (DG), glycerophosphoethanolamine (GPE), phosphatidic acid (PA), phosphatidylethanolamine (PE), and phosphatidylcholine (PC) have been associated with $\alpha$-syn aggregation-mediated pathophysiology of PD, DLB, and Alzheimer's diseases [72].

The $\alpha$-syn aggregates have been linked more precisely to the activation of an innate and adaptive immune system that includes microglial cell activation, proinflammatory cytokine generation, and the loss of dopaminergic neurons in the substantia nigra pars compacta region of the brain $[73,74]$. Studies have also shown $\alpha$-syn to be a key player in lipid metabolism regulation, dopamine production, and inflammatory responses [75-82]. $\alpha$-syn activity in these roles is dependent on the binding and attraction of $\alpha$-syn to negatively charged lipids such as GPE, TAG, DAG, GPI, cardiolipin (CL), docosahexaenoic acid (DHA), gangliosides, and other acidic phospholipids that influence the conformational changes and catalysis of the formation of abnormal species of $\alpha$-syn, which lead to the activation of immune inflammation and neurodegeneration in PD [83-87]. Overall, the improper metabolism of several lipids triggers the abnormal formation of $\alpha$-syn, which propagates brain inflammation in PD and other alphasynucleinopathies; however, this aspect has not received much focus in the field. Therefore, the underlying discussion in this paper explored several lipids and their link to $\alpha$-syn abnormalities, and the induction of a variety of innate and adaptive immune players and their reactions that spark neuroinflammation in PD. Understanding the relationship between these biochemicals and their impact on the induction of neuroimmune inflammation may reveal alternative treatments and therapies for PD.

\section{Triglyceride-Induced $\alpha$-syn Abnormalities in PD}

Triglyceride (TG) is also known as triacylglycerol (TAG), which is an ester derived from glycerol and three fatty acids. TAG storage primarily occurs in hepatocytes. Under normal circumstances on a daily basis, the liver causes the processing of large quantities of fatty acids but stores only small amounts in the form of TAG [88]. This is because the rates of acquisition of FA-by uptake from the plasma and from de novo synthesis within the liver-are balanced by rates of FA oxidation and secretion into plasma as TG-enriched, very low-density lipoprotein (VLDL-TG). The relatively small quantities of TAG stored 
within the liver are localized in cytoplasmic lipid droplets, which provide energy to the biological system.

Hypertriglyceridemia results from the accumulation of TG-rich lipoproteins (e.g., VLDL, VLDL remnants, and chylomicrons) in the bloodstream. This condition is very often the result of genetic and environmental factors, but can also result from specific genetic disorders, such as hypertriglyceridemia, familial combined hyperlipidemia, familial dysbetalipoproteinemia, familial chylomicronemia, and aging [89,90]. Excess TAG making and storage have been observed in obesity, arteriosclerosis, strokes, heart attacks, pancreatitis, and preeclampsia [91-96]. $\alpha$-syn accumulation in response to lipid droplets with high levels of TAG has been observed in many studies [97]. In HeLa and hippocampal neurons of certain A53T mutants, abnormal hydrolysis of stored TAG was associated with increased intracellular accumulation and enhanced activity of the acyl-CoA synthetase enzyme, which causes the formation of acyl-CoA and beta-oxidation responsible for biosynthesis of glycerophospholipids and sphingolipids [97]. Conversely, an increase in mutant $\alpha$-syn leads to an increase in TAG hydrolysis, and consequently a decrease in intracellular TAG in A53T and A30P transgenic mice and of PD patients, which suggests a link between abnormal lipid metabolism and $\alpha$-syn aggregation [98-100]. Low levels of TAGs in serum and plasma of mouse models and human patients with PD (Tables 1 and 2) and their link to $\alpha$-syn accumulation and aggregation have been observed in many studies [97-100], which suggests that TAG-induced $\alpha$-syn abnormalities process the disease in PD.

\section{Glycerophosphoethanolamine (GPE)-Induced $\alpha$-syn Abnormalities in PD}

Glycerophosphoethanolamine (GPE) is involved in cell membrane metabolism [101,102]. However, higher levels of GPE have been linked to liver cirrhosis and Alzheimer's disease $[101,103]$. GPE has been shown to play a role in enhancing the preferential binding of acidic phospholipids to $\alpha$-syn, and the resultant increases in $\alpha$-syn aggregation concluded that GPE is vital for the induction of $\alpha$-syn abnormalities in PD [43]. GPE has also been associated with the formation of ion channels in monomeric wild-type, E46K mutant, and A53T mutant $\alpha$-syn models. The monomeric form of wild-type $\alpha$-syn and its mutants formed ion channels with membranes containing 50\% GPE, while oligomeric $\alpha$-syn lacked such formation of ion channels and PE requirements. These observations indicate that interactions between monomeric $\alpha$-syn and GPE are critical for the abnormal development of $\alpha$-syn in PD [104].

\section{Diglyceride (DG)-Induced $\alpha$-syn Abnormalities in PD}

Diglyceride (DG), or diacylglycerol (DAG), is a class of lipid, which is composed of two fatty acids chains covalently bonded to one glycerol through ester linkages. Dietary fat is mainly composed of TAG since it cannot be absorbed by the digestive system, hence TAG must first be enzymatically digested into monoacylglycerol (MAG), diacylglycerol (DAG), or free fatty acids. DAG is a precursor to TAG, which is formed by the addition of a third fatty acid to the DAG under the catalysis of diglyceride acyltransferase. DAG can be phosphorylated to phosphatidic acid by diacylglycerol kinase. DAG synthesis involves the hydrolysis of the phospholipid phosphatidylinositol 4, 5-bisphosphate $\left(\mathrm{PIP}_{2}\right)$ by the enzyme phospholipase C (PLC) (a membrane-bound enzyme), which through the same reaction produces inositol trisphosphate $\left(\mathrm{IP}_{3}\right)$. Although IP3 diffuses into the cytosol, DAG remains within the plasma membrane due to its hydrophobic properties. $\mathrm{IP}_{3}$ stimulates the release of calcium ions from the smooth endoplasmic reticulum, whereas DAG is a physiological activator of protein kinase C (PKC) $[105,106]$. Increased intracellular DAGinduced activation of PKC has shown decreased insulin-stimulated IRS-1/IRS-2 tyrosine phosphorylation, PI3K activation and downstream insulin signaling in liver and skeletal muscles [107]. The DAG kinase enzyme converts DAG to PA, while the DAG acyltransferase enzyme is responsible for the conversion of DAG to TAG [108]. Studies have shown that a strong binding of 18:1/18:1 species of PA to $\alpha$-syn causes its aggregation, mainly due to 
high DAG and low PA levels in PD $[109,110]$. These findings suggest that the abnormal interaction between the DAG-PA axis triggers $\alpha$-syn aggregation in PD.

\section{Polyunsaturated-Fatty-Acid (PUFA)-Induced $\alpha$-syn Abnormalities in PD}

Polyunsaturated fatty acid (PUFA) is a fatty acid that contains more than one double bond in the glycerol backbone; on the basis of their carbon backbone length, they are classified in two groups, i.e., short-chain PUFA (SC-PUFA), with 18 carbon atoms; and long-chain PUFA (LC-PUFA), with 20 or more carbon atoms [111]. Several such PUFA, including $\omega-6$ (or $n-6$ ), arachidonic acid (ARA; 20:4n-6), and $\omega-3$ (or n-3), eicosapentaenoic acid (EPA; 20:5n-3), and docosahexaenoic acid (DHA; 22:6n-3) were reported to be essential for (1) neuronal membrane and visual brain development, (2) maintenance of neuronal membrane fluidity and permeability, (3) controlling of cardiovascular and coronary artery function, and (4) regulation of inflammation [112-122]. The abnormal ratio between dietary $\omega-6$ (n-6) to $\omega-3$ (n-3) PUFA has been linked to the pathophysiology of cancer, rheumatoid arthritis, atherosclerosis, and obesity [123-125].

$\alpha$-syn and PUFA are involved in synaptic vesicle recycling [126]. However, prolonged interaction of PUFA and monomeric $\alpha$-syn causes $\alpha$-syn fibril formation and its oligomerization, which supports the formation of Lewy-like proteinaceous bodies in the cytoplasm [81,127-135]. Interaction of $\alpha$-syn with 4-hydroxy-2-nonenal, a product of PUFA peroxidation, seems to produce the same result, but was also found to prevent the passage of fibrils into Lewy Bodies [127,129,130]. PUFA levels have been found to be altered in many models of PD. Several PUFA, specifically linoleic acid (LA), docosatetraenoic acid (DSA), eicosapentaenoic acid (EPA), and osbond acid (OBA), were elevated in mesencephalic (MES) neuronal cells of PD patients [135]. In mice models, levels of LA, EPA, and eicosatrienoic acid (ESA) were also elevated in MES neurons [81] and PD brains [135]. Two PUFAs of special note in $\alpha$-syn interactions are docosahexaenoic acid (DHA) and arachidonic acid (ARA). $\alpha$-syn levels contribute to an increase in ARA and DHA81. Transmission electron microscopy, electrophoresis of native gels, and fluorescence assays with thioflavin indicate that DHA and ARA trigger $\alpha$-syn oligomerization and cause an immediate transformation of $\alpha$-syn to its helical conformation [136,137]. Coincidentally, other studies revealed that $\alpha$-syn has a role in the addition of substrates to acyl-CoA synthetase. As a consequence, $\alpha$-syn's addition of substrates allows control of the brain level of PUFA [138]. These observations indicate that $\alpha$-syn and PUFAs co-regulate each other via complex interactions [81]. Prolonged exposure of DHA to $\alpha$-syn causes $\alpha$-syn oligomerization by activating the retinoic $X$ receptor and peroxisome proliferator-activated receptor gamma 2 [139], therefore resulting in the production of lipid droplets [137]. Furthermore, these lipid droplets could be remodeled by $\alpha$-syn and increase assemblage of amyloid fibrils that contain DHA [136]. Accordingly, levels of DHA and ARA were higher in the frontal cortex of PD patients. Conversely, their levels appeared lower in frontal cortex lipid rafts [140]. In mice models, ARA levels were elevated in the MES neurons [135], frontal cortex, striatum, midbrain synaptosomes, and striatal synaptosomes [141,142]. Furthermore, DHA was found to be elevated in MES DA neuronal cells and brains of PD patients, and it was concluded that increased DHA intake causes increased $\alpha$-syn toxicity [135]. A possible mechanism for this is the disruption of membrane integrity via leakage of small molecules out of the vesicles due to oligomeric $\alpha$-syn binding [143]. Interestingly, oligodendroglia cells that expressed both the wild-type and mutated A53T $\alpha$-syn resulted in fibril formation, thus solidifying the conclusion that elevated DHA affects $\alpha$-syn fibril formation [144]. Increased levels of several species of PUFA, i.e., $\alpha$ LA, EPA, ETA, and ARA in neurons of mouse models (Table 1) and DHA, LA, DSA, EPA, and OBA in neuronal cells and brains of human PD patients (Table 2), as well as their relation to $\alpha$-syn oligomerization, have been observed [81,127-135]. These findings suggest that several species of PUFA could develop $\alpha$-syn abnormalities in PD. 


\section{Sphingolipid-Induced $\alpha$-syn Abnormalities in PD}

Sphingolipids are molecules with lipid chains forming part of the cell lipid membrane and have been identified as inflammatory regulators of cellular pathways [145-147]. Sphingolipid metabolism typically begins with the production of ceramides, which are the major sphingolipids released during cellular metabolism, responsible for the degradation of sphingosine [148]. Such sphingosine is in turn phosphorylated by the isoenzymes sphingosine kinase 1 (SphK1) and sphingosine kinase 2 (SphK2) into sphingosine-1-phosphate (S1P) $[149,150]$. This specific pathway regulates cell growth, apoptosis, survival, and inflammation in several diseases, such as systemic lupus erythematosus, cancer, coronary artery disease, and the fibrotic diseases of the lungs, liver, and heart [151-160]. Abnormal synthesis of ceramides, sphingosine, and S1P have been linked to $\alpha$-syn aggregation in PD [161]. One source of ceramides and sphingosine for this pathway comes from the hydrolysis of glucosylceramide and glycosylsphingosine via acid $\beta$-glucosidase. Interestingly, mutations in the GBA1/Gba1 gene that encodes the enzyme acid $\beta$-glucosidase has been strongly associated with the development of PD, DLB, and lysosomal storage disease, (e.g., Gaucher disease) [18,162-167]. Studies have also shown the connection between lower levels of ceramides and $\alpha$-syn aggregation in PD patients [110,168-171]. Analysis of brains from postmortem PD patients revealed a direct relationship between increased glycosylsphingosine and $\alpha$-syn levels due to a lack of glycosylsphingosine hydrolysis into ceramides, which revealed an inverse relationship between such glycosylsphingosine and $\alpha$-syn levels in the brain [172]. These findings suggested that ceramide conversion to sphingosine seems to be a crucial step for $\alpha$-syn aggregation. Higher levels of sphingosines were associated with the formation of oligomeric $\alpha$-syn, which is attributed to fibril formation. Further conversion to S1P due to GBA deficiency also contributed to $\alpha$-syn aggregation [173]. Interestingly, increased levels of $\alpha$-syn inhibited phosphorylation of sphingosine to S1P and affected S1P-receptor-mediated signaling. Conversely, levels of ceramides, specifically monohexosylceramides, were found to be elevated in PD patients with GBA mutations. Accordingly, higher ceramide levels have been observed in the plasma, primary visual cortex, and CSF of PD patients [168,173-175]. This trend has also been observed in mice models of Lrrk2 and PINK1 [176,177]. Other sphingolipids, such as sphingomyelin (SM) and cerebrosides, have also had altered levels in PD models; for example, higher levels of SM have been found in plasma [175], the primary visual cortex [178] and ACC of humans with PD [168]. Elevated levels of SM and cerebrosides have been observed in substantia nigra of male PD patients [179]. Interestingly, SM was also observed to be lower in the ACC of PD [168] patients and the CSF of AD patients [174]. SM treatment of SK-N-SH neuronal cells increased the expression of $\alpha$-syn. One proposed pathway is that SM acts as a substrate for the ABCA5 transporter [180]. Although the mechanism remains unknown, higher levels of SM resulted in higher SM transportation and $\alpha$-syn accumulation, therefore linking SM metabolism to the pathogenesis of many LBDs. Cerebroside levels were observed to be higher and lower in the plasma [175] and frontal cortex, respectively [140]. Furthermore, decreased levels of cerebroside have been linked to increased levels of ceramides, therefore contributing to the formation of fibrils and aggregates [181]. Elevated neurons, olfactory bulbs, and brain levels of sphingolipids, i.e., sphingosine and ceramide, have been observed in mouse models of PD (Table 1). Similarly, several members of the sphingolipids, including sphingosine, SM, ceramide, cerebroside, and glucosylceramide have been observed in the plasma, fibroblast, neurons, frontal cortex, anterior cingulate cortex (ACC), primary visual cortex (PVC), substantia nigra, and other brain regions of human patients with PD (Table 2). Several such sphingolipids have been linked to $\alpha$-syn aggregation in PD [110,161,168-171], suggesting the importance of sphingolipids in the propagation of $\alpha$-syn-mediated pathophysiology in PD.

\section{Ganglioside-Induced $\alpha$-syn Abnormalities in PD}

Ganglioside (GAG) is an important component of the neuronal cell membrane, which is composed of a ceramide lipid tail attached through glycosidic linkage to a glycan head- 
group containing one or more sialic acid residues (e.g., n-acetylneuraminic acid) [182]. GAG is functionally involved in the formation of the neuronal membrane and conduction of neurotransmission processing [183-186]. GAG is synthesized in the Golgi apparatus and trafficked to different parts of the cells, such as the plasma membrane [187,188], endo-lysosomal system [189,190], endoplasmic reticulum (ER)-mitochondria contact sites [191,192], and the nuclear envelope $[193,194]$. In addition to PD, GAG deficiency has been also linked to several brain diseases, such as aging, neurodevelopmental diseases, Alzheimer's, and Huntington's disease [195-210].

$\alpha$-syn was determined to have a GM3-GAG-binding domain, and to therefore preferentially bind to GM3 [211]. Interestingly, this particular domain was found to resemble a domain responsible for the binding of amyloid proteins, which includes the binding of $\beta$-amyloid peptide, which forms amyloid plaques in Alzheimer's disease [211,212]. Decreased levels of GM1-GAG have been observed in the putamen [210] and substantia nigra of PD patients [210,213]. Elevated levels of GM2-GAG have been found in fibroblasts of PD patients [214]. Similarly, elevated levels of GM3-GAG were observed in plasma, cerebrospinal fluid, and brain regions of PD patients [210,215-217]. Elevated levels of several of the gangliosides, (e.g., GM1, GM2, and GM3) have been observed in plasma, fibroblasts, $\mathrm{SN}$, and brains of human patients with PD (Table 2). Altered levels of the GM1-GM2-GM3 axis have been linked to $\alpha$-syn aggregation PD [212,218-220]. These findings suggest the importance of the GM1-GM2-GM3 axis in the induction of $\alpha$-syn aggregation in PD.

\section{Glycerophospholipid-Induced $\alpha$-syn Abnormalities in PD}

Glycerophospholipids (GPL), or phosphoglycerides, are glycerol-based phospholipids that comprise at least one $\mathrm{O}$-acyl residue attached to the glycerol moiety. Several GPL species, such as phosphatidylcholine (PC), phosphatidylethanolamine (PE), and phosphatidylserine (PS) are abundant in mammalian cell membranes, which are critical for the formation of the cerebral structure and the steering of cognitive functions [221,222]. Alterations in GPL composition were observed in several brain diseases, such as schizophrenia, Huntington's, and Alzheimer's disease [222-225].

$\alpha$-syn shows preferential binding to negatively charged acidic lipids [87]. Due to the negative charge, its lysine residues become seamless acnes for $\alpha$-syn binding [226]. These findings suggest that $\alpha$-syn binding to PS and phosphoinositols (PIs), the most acidic forms of phospholipids, leads to the formation of $\alpha$-syn oligomers [227]. The phosphatidylinositol 4,5-bisphosphate is also the phosphorylated form of PI, and is termed as a phosphoinositide, which has also shown its tendency to interact with $\alpha$ - and $\gamma$-syn and cause their aggregation [228]. The binding of such PI seems to mostly occur in the presynaptic terminals of vesicles that show the presence of $\alpha$-syn, indicating the possible role of PI in $\alpha$-syn abnormalities [228,229]. Lower levels of PI and PS have been observed in the substantia nigra of PD patients [179]. Accordingly, $\alpha$-syn knockout mice showed increased PI and PS acylation [230], and $\alpha$-syn-deficient models of PD revealed an increase in DHA conversion to PI and PS [87]. Other studies have shown elevated levels of PS in fibroblasts, the frontal cortex, and the primary visual cortex $[110,178,214]$.

Phosphatidic acid (PA) is secondary lipid messenger that, as with PI, has roles in intracellular trafficking of vesicles [231]. Due to its acidic nature, PA has been found to preferentially bind to $\alpha$-syn residuals 1 to 102 [232]. Elevated levels of PA have been found in the plasma of PD patients [231,233]. Likewise, phosphatidylglycerol (PG) in micellar tubules has been shown to mitigate amyloid formation by membrane remodeling [234]. Along with PI and PS levels, PG levels are elevated in the frontal cortex of PD, AD, and LBD patients, thus highlighting its role in fibril formation in Lewy body disorders. Unlike the other glycerophospholipids, PE has recorded lower levels of expression in plasma, the visual cortex, and substantia nigra, and higher levels in the frontal cortex of PD models and patients $[140,178,235,236]$. PE was also found to aid in lipid vesicle binding to $\alpha$-syn by creating a monolayer curvature strain on these vesicles, and as such, $\alpha$-syn binding of them [43]. Altered levels of glycerophospholipids, i.e., CL in embryonic fibroblasts of mouse 
models of PD (Table 1), as well as PA, PC, PE, PS, PI, PG, and APG, have been found in the plasma, frontal cortex, visual cortex, fibroblasts, $\mathrm{SN}$, and brains of human patients with PD (Table 2). Several such glycerophospholipids have been associated with the formation of $\alpha$-syn oligomers $[227,229]$. These findings suggest that abnormal chemical reactions between glycerophospholipids and normal $\alpha$-syn promote $\alpha$-syn oligomerization in PD.

\section{Cholesterol-Induced $\alpha$-syn Abnormalities in PD}

Cholesterol is essential for cell membrane physiology, dietary nutrient absorption, reproductive biology, stress responses, salt and water balance, calcium metabolism, proper functioning of oncogenic $\mathrm{G}$ proteins, proteases of amyloid precursor protein, synapse formation, and synthesis of steroid hormones, bile acids, and vitamin D [237-241]. The human body produces around one gram of cholesterol/day [242]. Synthesis of cholesterol is a series process that starts with acetyl $\mathrm{CoA}$ and acetoacetyl-CoA, which are hydrated to form 3-hydroxy-3-methylglutaryl CoA (HMG-CoA), and subsequently reduced to mevalonate by HMG-CoA reductase enzyme [243]. Both dietary and synthesized de novo cholesterols are transported by lipoprotein particles through the circulatory system. The four major types of lipoproteins are chylomicron, very low-density lipoprotein (VLDL), low-density lipoprotein (LDL), and high-density lipoprotein (HDL), where chylomicrons and VLDL deliver TAG to cells, LDL delivers cholesterol to cells, and HDL is involved in reverse cholesterol transport [244,245].

The synthesis and utilization of cholesterol is a strongly controlled method that prevents its overdeposition of tissue. However, abnormal synthesis and utilization of cholesterol due to certain inherited diseases, infection, and/or unhealthy lifestyle, contributes to the development of hyperlipidemia and hypolipidemia [246-250]. Several illnesses, such as atherosclerosis, xanthomas, tangier, strokes, and cardiovascular diseases have been linked to high cholesterol levels [251-254]. Meanwhile, low cholesterol levels have been linked to cognitive defects (e.g., depression, suicide, anxiety, impulsivity, and aggression) in several brain sicknesses, such as trauma, hemorrhagic stroke, and Huntington's disease [255-261].

Studies have linked cholesterol abnormalities to $\alpha$-syn aggregation; for example, PARKN expression is one of the major dysfunctional genes in PD, which is controlled by cholesterol metabolism through ubiquitination of CD36, and in turn regulates the production of cholesterol [262]. Such cholesterol interaction has normal $\alpha$-syn accumulation and aggregation $[263,264]$. It was also demonstrated that decreased levels of cholesterol reduced the amount of $\alpha$-syn and mitigated the effects of its aggregation [265]. The exact role of cholesterol in the pathogenesis of PD is controversial, as human studies have found cholesterol levels to be both high [266] and low in plasma samples of PD patients [267]. Some studies showed that lower levels of cholesterol increased the risk of PD, while higher levels reduced the risk of PD [268,269]. Moreover, other studies showed no correlation between cholesterol levels or intake and PD risk [270]. In mice models, cholesterol levels were observed to be elevated in MEF cells [271] and lower in serum [272]. Interestingly, cholesterol levels have been found to be both high and low in mice astrocytes $[77,273]$ and fibroblast $[271,273]$. Overall, altered levels of cholesterol have been found in serum, fibroblasts, astrocytes, and MES. cells of mouse models of PD (Table 1), and abnormal levels of such cholesterol have been observed in the plasma and PVC of human patients with PD (Table 2). Overall, abnormal cholesterol production and its interaction to normal $\alpha$-syn caused $\alpha$-syn aggregation in both PD mouse models and patients [262-265]. These findings suggest that altered biochemistry of cholesterol and its linking to $\alpha$-syn subsidizes $\alpha$-syn aggregation in PD.

Table 1. Lipids linked to $\alpha$-syn abnormalities in mouse model of PD.

\begin{tabular}{cccccc}
\hline \multirow{2}{*}{ Family } & Types & $\begin{array}{c}\text { PD Mouse Model's } \\
\text { Alpha-Synuclein Abnormalities }\end{array}$ & Source & Levels & Reference \\
\hline \multirow{2}{*}{ Glycerolipid } & TAG & A53T mutant & Serum & Low & {$[272]$} \\
& NEFA & A53T mutant & Serum & Low & {$[272]$} \\
\hline
\end{tabular}


Table 1. Cont.

\begin{tabular}{|c|c|c|c|c|c|}
\hline Family & Types & $\begin{array}{c}\text { PD Mouse Model's } \\
\text { Alpha-Synuclein Abnormalities }\end{array}$ & Source & Levels & Reference \\
\hline \multirow{6}{*}{ PUFA } & \multirow{2}{*}{$\alpha-\mathrm{LA}$} & Transgeneic alpha-synuclein mice & $\begin{array}{l}\text { MES } \\
\text { Neurons }\end{array}$ & Induces & [81] \\
\hline & & $\begin{array}{l}\text { alpha-synuclein null } \\
\text { C57B16 background }\end{array}$ & $\begin{array}{l}\text { MES } \\
\text { Neurons }\end{array}$ & High & [135] \\
\hline & EPA & Transgeneic alpha-synuclein mice & $\begin{array}{l}\text { MES } \\
\text { Neurons }\end{array}$ & Induces & [81] \\
\hline & ETA & a-syn null C57B16 background & $\begin{array}{l}\text { MES } \\
\text { Neurons }\end{array}$ & High & [135] \\
\hline & \multirow[t]{2}{*}{ ARA } & $\begin{array}{l}\text { alpha-synuclein null } \\
\text { C57B16 background }\end{array}$ & $\begin{array}{l}\text { MES } \\
\text { Neurons }\end{array}$ & High & [135] \\
\hline & & $\begin{array}{l}\text { Fabp3KO mice with } \\
\text { MPTP treatment }\end{array}$ & PC12 cells & High & [274] \\
\hline MUFA & $\mathrm{OA}$ & A53T overexpressing cells & $\begin{array}{c}\text { MES } \\
\text { Neurons }\end{array}$ & Low & [135] \\
\hline Glycerophospholipid & CL & PINK1 KO & $\begin{array}{l}\text { Embryonic } \\
\text { fibroblasts }\end{array}$ & Low & [275] \\
\hline \multirow{3}{*}{ Sphingolipids } & Sphingosine & $\begin{array}{l}\text { GbaL444P/KO SNCAT and } \\
\text { GbaKO/KO SNCAT }\end{array}$ & Neuron & Induce & [173] \\
\hline & \multirow{2}{*}{ Ceramide } & Lrrk2KO mice & Brain & High & [176] \\
\hline & & PINK1 KO & $\begin{array}{l}\text { Olfactory } \\
\text { bulb }\end{array}$ & High & [177] \\
\hline \multirow{6}{*}{ Sterol } & \multirow{6}{*}{ Cholesterol } & DJ1 KO & $\begin{array}{l}\text { Embryonic } \\
\text { fibroblasts }\end{array}$ & Low & [273] \\
\hline & & DJ1 KO & Astrocyte & Low & [273] \\
\hline & & GBA1 KO & Fibroblasts & Low & [271] \\
\hline & & PRKN KO & MEF cells & High & [276] \\
\hline & & A53T mutant & Serum & Low & [272] \\
\hline & & alpha-synuclein gene-ablated mice & Astrocyte & High & [77] \\
\hline
\end{tabular}

Polyunsaturated fats (PUFA), monounsaturated fats (MUFA), triacylglycerols (TAGs), non-esterified fatty acids, $\alpha$-linoleic acid ( $\alpha$-LA), eicosapentaenoic acid (EPA), eicosatetraenoic acid (ETA), arachidonic acid (ARA), oleic acid (OA), cardiolipin (CL), alpha-synuclein (a syn), knockout (KO), T (Tansgenic), and mesencephalic (MES).

Table 2. Lipids linked to $\alpha$-syn abnormalities in human patients with PD.

\begin{tabular}{|c|c|c|c|c|}
\hline Family & Types & Source & Level & Reference \\
\hline Glycerolipid & TAG & Plasma & Low & {$[217,236,277]$} \\
\hline \multirow{8}{*}{ PUFA } & \multirow{2}{*}{ DHA } & MES & High & [135] \\
\hline & & Brain & High & [135] \\
\hline & \multirow{2}{*}{ LA } & MES & High & [135] \\
\hline & & Brain & Low & [135] \\
\hline & \multirow{2}{*}{ DSA } & MES & High & [135] \\
\hline & & Brain & High & [135] \\
\hline & EPA & MES & High & [135] \\
\hline & OBA & MES & High & [135] \\
\hline Eicosanoids & PGL J2 & SK-N-SH cells & Induces & [278] \\
\hline \multirow{16}{*}{ Glycerophospholipids } & PA & Plasma & Low & [235] \\
\hline & PC & Frontal cortex & Low & [110] \\
\hline & \multirow{5}{*}{ PE } & $\mathrm{SN}$ & Low & [235] \\
\hline & & Visual cortex & Low & [178] \\
\hline & & Plasma & Low & [236] \\
\hline & & Frontal cortex & High & [140] \\
\hline & & Plasma & Low & [175] \\
\hline & \multirow{5}{*}{ PS } & Plasma & Low & [236] \\
\hline & & Fibroblast & High & [214] \\
\hline & & Frontal cortex & High & [110] \\
\hline & & Visual cortex & High & [178] \\
\hline & & Fibroblast & High & [214] \\
\hline & \multirow[t]{2}{*}{ PI } & Frontal cortex & High & [140] \\
\hline & & $\mathrm{SN}$ & Low & [179] \\
\hline & PG & Frontal cortex & High & [110] \\
\hline & APG (acyl PG) & Plasma & Low & [175] \\
\hline
\end{tabular}


Table 2. Cont.

\begin{tabular}{|c|c|c|c|c|}
\hline Family & Types & Source & Level & Reference \\
\hline \multirow{21}{*}{ Sphingolipid } & Sphingosine & Neurons & Induce & [173] \\
\hline & \multirow{6}{*}{ Ceramide } & Plasma & High & [173] \\
\hline & & Plasma & Low & [170] \\
\hline & & Plasma & Low & [175] \\
\hline & & Frontal cortex & Low & [110] \\
\hline & & $\mathrm{ACC}$ & Low & [39] \\
\hline & & PVC & High & [279] \\
\hline & \multirow{6}{*}{$\mathrm{SM}$} & Plasma & High & [175] \\
\hline & & $\mathrm{ACC}$ & Low & [279] \\
\hline & & $\mathrm{ACC}$ & High & [279] \\
\hline & & PVC & High & [178] \\
\hline & & $\mathrm{SN}$ & High & [179] \\
\hline & & $\mathrm{SN}$ & High & [179] \\
\hline & \multirow[t]{2}{*}{ Cerebroside } & Plasma & High & [175] \\
\hline & & Frontal cortex & Low & [140] \\
\hline & GlcCer & Plasma & High & [217] \\
\hline & GM3 & Plasma & High & [217] \\
\hline & & Fibroblast & High & [214] \\
\hline & GIV12 & Brain & High & [218] \\
\hline & GM1 & $\mathrm{SN}$ & Low & [213] \\
\hline & Sulfatide & Frontal cortex & High & {$[110]$} \\
\hline \multirow{3}{*}{ Sterol } & \multirow{3}{*}{ Cholesterol } & Plasma & Low & [267] \\
\hline & & Plasma & High & [266] \\
\hline & & PVC & High & {$[178]$} \\
\hline \multirow{3}{*}{ Phospholipids } & $\mathrm{CP}$ & Frontal cortex & High & [110] \\
\hline & \multirow{2}{*}{ EP } & Frontal cortex & High & [110] \\
\hline & & Plasma & Low & {$[175]$} \\
\hline $\begin{array}{l}\text { Polyunsaturated fats (Pt } \\
\text { traenoic acid (DSA), eic } \\
\text { (PA), phosphatidylcholi } \\
\text { (PI), phosphatidylglycer } \\
\text { choline plasmalogen (CI } \\
\text { cingulate cortex (ACC), }\end{array}$ & $\begin{array}{l}\text { ylglycerols (TA } \\
\text { noic acid (EPA } \\
\text { losphatidylser } \\
\text { lphosphatidy } \\
\text { amine plasmal } \\
\text { ry visual corte }\end{array}$ & $\begin{array}{l}\text { locosahexaenoic } \\
\text { ond acid (OBA) } \\
\text { S), phosphatidyl } \\
\text { rol (APG), gluco } \\
\text { EP), mesencepha }\end{array}$ & $\begin{array}{l}\text { PHA), lin } \\
\text { aglandin } \\
\text { lamine (1 } \\
\text { mide (Gl } \\
\text { ES), subst }\end{array}$ & $\begin{array}{l}\text { d (LA), doce } \\
\text { nosphatidic } \\
\text { phatidyline } \\
\text { ngliosides ( } \\
\text { ra (SN), ant }\end{array}$ \\
\hline
\end{tabular}

\section{Lipid- $\alpha$-syn-Proinflammatory Cytokine Pathway in PD}

The capacity of the immune system relies heavily on CNS macrophages (M $\Phi s)$ known as microglial cells $[280,281]$. Foamy M $\$$ s with lipid droplets, which store TAG and cholesterol esters (CEs), are found in various disease states, including atherosclerotic lesions tuberculosis, multiple sclerosis, certain cancers, white adipose tissue during obesity, and in bronchoalveolar lavage from individuals suffering from vaping-related lung disease [282-285]. The lipid droplets can act as energy stores, since TAG lipolysis releases fatty acids (FAs) for mitochondrial oxidation (FAO), a process that relies on long-chain FA conversion into acylcarnitines by the enzyme Cpt1a [283]. However, in $\mathrm{M} \Phi \mathrm{s}$, proinflammatory signals result in diminished FAO and increased TAG synthesis with development of the lipid droplets [284]. Enhanced TAG synthesis causes $M \Phi$ s activation with increased lipid droplet formation, and massive generation of proinflammatory cytokines (e.g., IL1 $\beta$, IL6, and PGE2). However, the deficiency of TAGs prevents the lipid droplets' development and the production of proinflammatory cytokines [286]. glucosylceramide and glucosphingosine-loaded $\mathrm{M} \phi$ s have been directly involved in the massive generation of several proinflammatory cytokines and chemokines that lead to tissue destruction in Gaucher disease [163,164,166,167,287-290].

Microglial cell activation and proinflammatory cytokines (e.g., TNF $\alpha$, IL1 $\beta$, IL6, I-8, IL12, MIP1 $\alpha$, and IFN $\gamma$ ) have been severely altered in many tissues and models of PD [291-296]. The general trend observed of glycerolipids is that they are lower in PD models [272]. Both decreased and increased TAG levels and accumulated $\alpha$-syn have been found in A53T mutants [97-100,272]. In A53T mutants, serum levels of TAGs and non-esterized fatty acids (NEFA) were decreased, but elevated levels of TNF $\alpha$ mRNA expression were found in the brain. Furthermore, expression of Sirt2, a gene responsible for mitigating inflammatory damage, was significantly decreased [272]. A possible mechanism for this is stimulation of hepatic lipid secretion into the serum and an increase in lipolysis. 
This results in increased VLDL hepatic TAGs [297]. VLDL cholesterol is secreted from the liver to supply VLDL TAGs to the body's tissues [298]. Interestingly, lower levels of cholesterol were also found in the serum of the A53T mice [272]. Therefore, higher levels of TAGs and cholesterol may mitigate the pathogenesis of PD. However, as mentioned before, the effect of cholesterol intake on PD is not well understood and very controversial [235].

Recent studies in prostaglandin E2 (PGL E2) have revealed its significance in enhancing inflammation [299]. In animal models of PD, LPS stimulation and $\alpha$-syn fibrils resulted in excess secretion of PGL E2 [300-302]. When secreted, PGL E2 will bind to EP1-4 receptors. This results in alterations of intracellular cAMP that will activate specific kinases and result in the activation of different inflammatory pathways [303]. Accordingly, increased levels of PGL E2 have been observed in the CSF of PD patients with cognitive impairments. In the CSF, levels of cytokines were also measured and found to be significantly altered. TNF $\alpha$ and IFN $\gamma$ levels were lower, while IL1 $\beta$ and IL6 levels were elevated [304]. Therefore, it appears that increased levels of PGL E2 result in cytokine alterations and neuroinflammation. Conversely, lower levels of PGL E2 have been observed in the astrocytes of DJKO mice. Although similar to the observation in the CSF of PD patients, astrocytes had decreased expression of TNF $\alpha$ [305]. A possible explanation for this difference lies in the different roles of the different EP receptor subtypes (EP1-EP4) [235]. In hydroxydopamine (6-OHDA)-treated mice, the knockout of EP1 and agonist of EP2 resulted in neuroprotection against neurotoxicity [235,306,307]. In the Substantia Nigra of 1-methyl-4-phenyl-1,2,3,6tetrahydropyridine (MPTP)-treated mice, the receptor EP4 was linked to dopaminergic neuron loss and neurodegeneration [235,308]. Therefore, the role of PGL E2 and enhancing inflammation may be dependent upon which EP receptor it binds [235].

Beta-galactosylceramide ( $\beta$-GalCer) and sulfatides are two sphingolipids that contribute to neuroinflammation [309]. $\beta$-GalCer is a precursor of sulfatides, and both are present in the pancreas [310] and whole blood [311]. Cytokines, such as IL1 $\beta$, IL6, TNF $\alpha$, and IFN $\gamma$ are known to have major influences on the pancreas [309,312]. Accordingly, altered levels of cytokines and these sphingolipids have been found in peripheral blood. When stimulated with LPS, blood cells revealed elevated levels and lower levels of $\beta$-GalCer and sulfatides, respectively. In blood cells with elevated $\beta$-GalCer, higher levels of TNF $\alpha$, IL1 $\beta$, IL6, IL8, and MIP1 $\alpha$ were detected. In blood cells with lower levels of sulfatides, TNF $\alpha$, IL1 $\beta$, IL6, IL8, IL12, and MIP1 $\alpha$ were significantly lowered. In conclusion, $\beta$-GalCer increased cytokine production, and sulfatides reduced cytokine production [309]. The release of $\beta$ -GalCer recruits blood leukocytes, thus contributing to inflammation [313]. Sulfatides have been recently studied for their immunomodulating effects on dendritic cells in asthma [314]. These current findings of lower levels of sulfatides contributing to neuroinflammation solidify the immunomodulatory effects found in the previous asthma study [309] .

Increases in damage-associated molecular patterns (DAMPs), including endogenous alarm signals as well as pathogen-associated molecular patterns (PAMPs), have been recognized in many immunological cells, including dendritic cells (DCs), M $\phi$ s, and polymorphonuclear neutrophils (PMNs), which trigger innate and adaptive immune inflammation in several diseases [315-319]. Two classical pathways of antigen presentation have been described for the presentation of endogenous antigens on major histocompatibility complex I (MHC class I) molecules, and the presentation of exogenous antigens, such as intracellular pathogens, on MHC class II molecules [320]. Both MHC I and MHC II are found to express on antigen-presenting cells, such as microglial cells, and dopaminergic neurons, and involved processing the antigen presentation to the surface of $\mathrm{CD} 4^{+} \mathrm{T}$ cells and $\mathrm{CD}^{+} \mathrm{T}$ cells [321,322]. The expression of MHC I and II can be induced in dopaminergic neurons in the substantia nigra, and $\alpha$-syn-peptide-stimulated $\mathrm{T}$ cells have shown the development of activated subsets of helper and cytotoxic $\mathrm{T}$ cells and increased production of proinflammatory cytokines [322,323]. Indeed, the $\mathrm{MHC} \mathrm{II}^{+}$and $\mathrm{MHC} \mathrm{I}^{+}$microglial cells and dopaminergic neurons, as well as increased brain infiltration of effector CD4 ${ }^{+}$ and $C D 8^{+} \mathrm{T}$ cell subsets, have been observed in animal models and human patients with PD $[18,324]$. Thus, the improper metabolism of several lipids initiates the abnormal produc- 
tion of $\alpha$-syn (Figure 1). The recognition of such $\alpha$-syn by MHC I/MHC II molecules and their presentation to the corresponding $\mathrm{T}$ cells causes massive brain generation of several proinflammatory cytokines, which leads to neurodegeneration in PD.

In contrast to the MHC II-mediated peptide antigen processing and presentation to $\mathrm{CD}^{+}$and $\mathrm{CD}^{+} \mathrm{T}$ cells [325-327], NKT cells are subsets of T cells that coexpress T-cell (CD3, $\alpha / \beta$ TCRs) and NKT (NK1.1)-cell surface receptors [328]. These cells recognize hydrophobic antigens presented by major histocompatibility complex class I-like molecules, such as CD1d. CD1d-restricted NKT cells are classified into two subsets, namely type I and type II. CD1d-restricted type I NKT cells express invariant T-cell receptors (TCRs) and react with lipid antigens, including the marine-sponge-derived glycolipid $\alpha$-galactosylceramide. On the contrary, CD1d-restricted type II NKT cells recognize a wide variety of antigens, including glycolipids, phospholipids, sulfatides, and hydrophobic peptides, by their diverse TCRs [329-340]. Five CD1 isoforms are present in humans and are classified into two groups based on sequence similarity: CD1a, $-b$, and -c constitute group I, while CD1d forms group II [341]. CD1e represents an intermediate between the two CD1 groups and acts as a chaperone to facilitate lipid transfer onto CD1b and CD1d [342].

Sphingolipid activator proteins (SAPs) are $\sim 10 \mathrm{kDa}$ glycoproteins that have differential affinity for various glycosphingolipids. They have been postulated to facilitate membrane extraction and/or membrane structure of specific glycosphingolipids to enhance their degradation [343]. In addition, of the four SAPs (A, B, C, D) that derived from a common precursor, prosaposin, SAP B has a significant ability to transfer lipids to the CD1d molecule [344]. Moreover, prosaposin-deficient mice fail to develop or stimulate invariant NKT cells [345,346], suggesting that SAPs are critical for the development of NKT cells. Most of the mycobacterial-derived lipids, e.g., mycolic acid, glucose-monomycolate, phosphatidylinositol mannoside [347], lipoarabinomannan, mannosyl- $\beta$-1-phosphoisoprenoid, and mannosyl- $\beta-1-$ mycoketide [348] bind to CD1 group 1. Mice express only two homologues of CD1d, i.e., CD1d1 and CD1d2 [329]. CD1d presents endogenous and exogenous lipid antigens to NKT cells in humans and mice [333,349]. The best-known subset of CD1drestricted NKT cells uses an invariant TCR $\alpha$ chain $(\mathrm{V} \alpha 14-\mathrm{J} \alpha 18$ in mice and V $\alpha 24-\mathrm{J} \alpha 18$ in humans), i.e., invariant NKT (iNKT) cells [350]. iNKT cells rapidly secrete IFN $\gamma$, IL4, IL17, and other cytokines upon TCR stimulation [350-352]. Activated iNKT cells in turn activate $M \Phi s$ and thereby impact subsequent immune inflammation [353]. These interactions highlight the critical role played by iNKT cells in bridging innate and adaptive immune responses in diseases, including cancer [354]; bacterial, viral, parasitic, and fungal infections [355-357]; and autoimmune diseases [358].

Several of the lipids have been found to link with the massive generation of proinflammatory cytokines (Table 3). Furthermore, upregulation of CD1d and increased infiltration of NKT cells have also been reported in PD [359,360]. Based on such observations, CD1d upregulation was postulated to be secondary to alterations in intracellular trafficking as a consequence of excess lipid accumulation. These findings potentially implicate these lipids as damage-associated molecular patterns that likely directly, and/or via CD1d-restricted binding of their presentation to NKT cells, fuel massive generation of proinflammatory cytokines that lead to neurodegeneration in PD.

Table 3. Lipids involved in direct activation of neuroinflammation via cytokine release.

\begin{tabular}{|c|c|c|c|c|c|c|}
\hline Class of Lipid & Lipids & $\begin{array}{l}\text { Mouse Models and } \\
\text { Human PD Patients }\end{array}$ & $\begin{array}{c}\text { Source and Level } \\
\text { of Lipid }\end{array}$ & Cytokine & $\begin{array}{l}\text { Source and Level of Cytokine } \\
\text { or Inflammatory Marker } \\
\text { (m for mRNA and } p \text { for Protein) }\end{array}$ & References \\
\hline \multirow{2}{*}{ Glycerolipids } & NEFA & A53T mutant mice & Serum $^{-}$ & TNF $\alpha$ & Brain $^{\mathrm{m}+}$ & [272] \\
\hline & TAG & A53T mutant mice & Serum $^{-}$ & $\mathrm{TNF} \alpha$ & Brain $^{\mathrm{m}+}$ & [272] \\
\hline \multirow{5}{*}{ Eicosanoids } & \multirow{5}{*}{ PGL E2 } & \multirow[t]{3}{*}{ DJ KO mice } & \multirow[t]{2}{*}{ Astrocyte $^{-}$} & $\mathrm{TNF} \alpha$ & Astrocytes $^{\mathrm{m}-}$ & \multirow[t]{2}{*}{ [305] } \\
\hline & & & & $\mathrm{TNF} \alpha$ & $\mathrm{CSF}^{-}$ & \\
\hline & & & \multirow{3}{*}{$\mathrm{CSF}^{+}$} & IL1 $\beta$ & $\mathrm{CSF}^{\mathrm{p}+}$ & \multirow{3}{*}{ [304] } \\
\hline & & impairment and dementia & & IL6 & $\mathrm{CSF}^{\mathrm{p}}+$ & \\
\hline & & & & INF $\gamma$ & $\mathrm{CSF}^{\mathrm{p}-}$ & \\
\hline
\end{tabular}


Table 3. Cont.

\begin{tabular}{|c|c|c|c|c|c|c|}
\hline Class of Lipid & Lipids & $\begin{array}{l}\text { Mouse Models and } \\
\text { Human PD Patients }\end{array}$ & $\begin{array}{c}\text { Source and Level } \\
\text { of Lipid }\end{array}$ & Cytokine & $\begin{array}{l}\text { Source and Level of Cytokine } \\
\text { or Inflammatory Marker } \\
\text { (m for mRNA and } p \text { for Protein) }\end{array}$ & References \\
\hline \multirow{11}{*}{ Sphingolipid } & \multirow{5}{*}{$\beta$-GalCer } & \multirow{5}{*}{$\begin{array}{l}\text { PHA- and LPS-stimulated } \\
\text { blood cells }\end{array}$} & \multirow{5}{*}{$\mathrm{PB}^{+}$} & $\mathrm{TNF} \alpha$ & $\mathrm{PB}^{\mathrm{p}+}$ & \multirow{5}{*}{ [309] } \\
\hline & & & & IL1 $\beta$ & $\mathrm{PB}^{\mathrm{p}+}$ & \\
\hline & & & & IL6 & $\mathrm{PB}^{\mathrm{p}+}$ & \\
\hline & & & & IL8 & $\mathrm{PB}^{\mathrm{p}+}$ & \\
\hline & & & & $\operatorname{MIP} 1 \alpha$ & $\mathrm{PB}^{\mathrm{p}+}$ & \\
\hline & \multirow{6}{*}{ Sulfatides } & \multirow{6}{*}{$\begin{array}{l}\text { PHA- and LPS-stimulated } \\
\text { blood cells }\end{array}$} & \multirow{6}{*}{$\mathrm{PB}^{+}$} & $\mathrm{TNF} \alpha$ & $\mathrm{PB}^{\mathrm{p}-}$ & \multirow{6}{*}{ [309] } \\
\hline & & & & IL1 $\beta$ & $\mathrm{PB}^{\mathrm{p}-}$ & \\
\hline & & & & IL6 & $\mathrm{PB}^{\mathrm{p}-}$ & \\
\hline & & & & IL8 & $\mathrm{PB}^{\mathrm{p}-}$ & \\
\hline & & & & IL12 & $\mathrm{PB}^{\mathrm{p}-}$ & \\
\hline & & & & $\mathrm{MIP} 1 \alpha$ & $\mathrm{PB}^{\mathrm{p}-}$ & \\
\hline \multirow[t]{2}{*}{ Sterol } & Cholesterol & A53T mutant mice & Serum ${ }^{-}$ & $\mathrm{TNF} \alpha$ & Brain $^{\mathrm{m}+}$ & [272] \\
\hline & & \multicolumn{5}{|c|}{$\begin{array}{l}\text { Non-esterified fatty acids (NEFA), triacylglycerols (TAGs), prostaglandin (PGL), galactosylceramide (GalCer), } \\
\text { Parkinson's disease (PD), polyhydroxyalkanoates (PHA), lipopolysaccharide (LPS), cerebral spinal fluid (CSF), } \\
\text { peripheral blood (PB), tumor necrosis factor (TNF), interleukin (IL), interferon (INF), macrophage inflammatory } \\
\text { protein (MIP), protein expression (p), mRNA expression (m), high levels of expression (+), and low levels } \\
\text { of expression }(-) \text {. }\end{array}$} \\
\hline
\end{tabular}

\section{Lipid- $\alpha$-syn-ROS Pathway in PD}

Reactive oxygen species (ROS) are highly reactive, diffusible molecules, which generate intracellularly and extracellularly for the persistence of the host defense against infectious agents and biochemical insults [361-363]. ROS is involved in cancer, atherosclerosis, angiogenesis, diabetes, aging, and neurological degeneration, and known to promote oxidative stress (OS) in several diseases, including age-related macular degeneration, cataracts, and uveitis [364-368]. Several studies have shown that lipid metabolisms contribute to the induction of oxidative damage and tissue inflammation [369]. The roles of various enzymes and lipids such as COX-2, cPLA2, ARA, and prostaglandin (PGL) have been associated with ROS generation [370]. ARA functions comprise the healing of skeletal muscle and early neurological development [371,372]. Its first contribution to inflammation was recognized in 1984, when the administration of anti-inflammatory drugs inhibited production of inflammatory PGL [373]. Certain mediators, such as calcium and cPLA2, caused the phospholipid-membrane-mediated release of ARA [374]. MTPT-induced mouse models of PD with an E-EPA diet showed increased levels of ARA, COX-2, CPLA2, and iNOS in several brain regions, including the frontal cortex and striatum, supporting the connection between ARA metabolism and the OS [110,141]. Elevated levels of $\alpha$-LA have been detected in MES neurons and certain brain regions, i.e., the frontal cortex and striatum, of $\alpha$-syn mouse models and human patients with PD [81,135,141]. $\alpha$-LA is a major precursor for ARA $[375,376]$. It is therefore possible that $\alpha$-LA could convert to ARA and contribute to OS-mediated neuroinflammation in PD. However, future research is needed to confirm this possibility for developing PD pathogenesis. PGL is a lipid mediator produced from ARA via COX-2 [299]. Many studies have reported both lower and higher levels of PGL E2 in PD [304,305], but in terms of overexpression of COX-2, lower levels of PGL E2 have been detected in the striatum, hippocampus, cortex, and astrocyte of mouse models [305,377]. However, reduced levels of 15-F2t-IsoP, which are the marker of OS, were observed in the striatum and cortex of mice with lower PGL E2 [377]. This contradicts the suggestion that the creation of ROS is favored over PGL E2. Therefore, further investigation into the levels of PGL E2 and OS-mediated inflammation is warranted.

Several other acidic lipids such as CL, which is present in the inner membrane of the mitochondria, have been linked to OS and the pathogenesis of PD [275,378-381]. Lower levels of CL and increased palmitate has been associated with cytochrome c release [382], oxidative stress [149], inflammation [383], and $\alpha$-synucleopathies [384-386]. Therefore, lower CL levels seem to contribute to neuroinflammation via higher levels of $\alpha$-syn and lower levels of palmitate in PD. Furthermore, cholesterol levels in male DJ KO mice 
contributed to OS [106]. The low-density lipoprotein receptor (LDLR) produces LDLs that carry cholesterol. This receptor is also a downstream target of DJ1. Furthermore, when stimulated with $\mathrm{H}_{2} \mathrm{O}_{2}$, cholesterol levels decreased in embryonic fibroblasts and astrocytes. This therefore indicates a relationship between OS and cholesterol in PD [106].

As mentioned above, DHA contributes to $\alpha$-syn-mediated neuroinflammation, but a recent study introduces its role in OS-mediated neuroinflammation. In the anterior cingulate cortex of postmortem PD patients, DHA and DPA levels were elevated. To indicate $\mathrm{OS}$ and oxidation of tissues, F2-isoprotane levels were tested and found to be elevated [279]. This indicates that higher DHA levels induce oxidative stress. However, in PC12 cells, DHA shows a neuroprotective role against OS [387]. Therefore, the exact role of DHA in promoting oxidative stress is not well-understood.

The link between lipid metabolism and oxidative damage-induced neuroinflammation has also been observed [370]. Several of the proinflammatory cytokines, i.e., TNF $\alpha$, IL1 $\beta$, and IFN $\gamma$, caused cellular and mitochondrial ROS production [388-395]. Increased levels of NOS, a product of NF- $\mathrm{B}$ gene expression, were observed in astrocytes [305]. Furthermore, the lipid-induced activation NF- $\mathrm{B}$ pathway has been linked to inflammation by regulation of inflammasomes and stimulation of cytokines and chemokines [396]. ROS-induced oxidative damage has been observed in DJ1, PINK1, PARKN, SNCA, and LRRK2 familial $P D$ [397]. Several lipids are involved in the generation of such proinflammatory cytokines and ROS in mouse models and human patients with PD (Tables 3 and 4) suggesting the involvement of the lipid- and/or $\alpha$-syn-induced activation NF- $k B$ pathway's contribution to the generation of proinflammatory cytokines and ROS that lead to neurodegeneration in PD.

Table 4. Lipids and their levels involved in oxidative stress-mediated neuroinflammation.

\begin{tabular}{|c|c|c|c|c|c|c|}
\hline Class of Lipid & Lipids & $\begin{array}{c}\text { Mouse Models and } \\
\text { Human Patients with PD }\end{array}$ & $\begin{array}{l}\text { Source and } \\
\text { Level of Lipid }\end{array}$ & $\begin{array}{c}\text { Reactive } \\
\text { Oxygen Species }\end{array}$ & $\begin{array}{c}\text { Source and Level of } \\
\text { Reactive Oxygen Species }\end{array}$ & References \\
\hline \multirow[t]{2}{*}{ Eicosanoids } & \multirow[t]{2}{*}{ PGL E2 } & 6-OHDA treated mice & $\begin{array}{c}\text { Striatum } \\
\text { Hipp }^{-} \\
\text {Cortex }^{-}\end{array}$ & 15-F2t-IsoP & $\begin{array}{l}\text { Striatump }{ }^{\mathrm{p}-} \\
\text { Cortex }^{\mathrm{p}-}\end{array}$ & {$[377]$} \\
\hline & & DJKO mice & Astrocyte ${ }^{-}$ & $\begin{array}{l}\text { NOS2 } \\
\text { COX2 }\end{array}$ & $\begin{array}{l}\text { Astrocytes }^{\mathrm{m}+} \\
\text { Astrocytes }^{\mathrm{m}+}\end{array}$ & [305] \\
\hline \multirow[t]{2}{*}{ Glyercophospholipids } & \multirow[t]{2}{*}{ CL } & $\begin{array}{l}\text { PINK1 KO } \\
\text { mice }\end{array}$ & $\begin{array}{l}\text { Embryonic } \\
\text { fibroblast }^{-}\end{array}$ & Palmitate & Embryonic fibroblast $^{-}$ & {$[275]$} \\
\hline & & Thy $1 \alpha$-syn mice & Brain $^{-}$ & $\mathrm{n} / \mathrm{a}$ & $\mathrm{n} / \mathrm{a}$ & [386] \\
\hline \multirow[t]{2}{*}{ Sterol } & \multirow[t]{2}{*}{ Cholesterol } & DJ1 KO & $\begin{array}{l}\text { Embryonic } \\
\text { fibroblasts }^{-}\end{array}$ & $\mathrm{H}_{2} \mathrm{O}_{2}$ & D2 Cells ${ }^{+}$ & {$[273]$} \\
\hline & & DJ1 KO & Astrocyte ${ }^{-}$ & $\mathrm{H}_{2} \mathrm{O}_{2}$ & D2 Cells ${ }^{+}$ & [273] \\
\hline \multirow{8}{*}{ PUFA } & \multirow{2}{*}{$\alpha-\mathrm{LA}$} & $\begin{array}{c}\text { MPP + treated mice on } \\
\text { E-EPA diet }\end{array}$ & Frontal cortex ${ }^{+}$ & $\begin{array}{l}\text { cPLA2 } \\
\text { COX2 }\end{array}$ & $\begin{array}{l}\text { Striatum } \\
\text { Striatum }^{\mathrm{m}+}\end{array}$ & {$[141]$} \\
\hline & & $\begin{array}{c}\mathrm{MPP}+\text { treated mice on } \\
\text { E-EPA diet }\end{array}$ & Striatum $^{+}$ & $\begin{array}{l}\text { cPLA2 } \\
\text { COX2 }\end{array}$ & $\begin{array}{l}\text { Striatum }{ }^{\mathrm{m}+} \\
\text { Striatum }^{\mathrm{m}+}\end{array}$ & {$[141]$} \\
\hline & \multirow{4}{*}{ ARA } & $\begin{array}{c}\mathrm{MPP}+\text { treated mice on } \\
\text { E-EPA diet }\end{array}$ & Frontal cortex ${ }^{+}$ & $\begin{array}{l}\text { cPLA2 } \\
\text { COX2 }\end{array}$ & $\begin{array}{l}\text { Striatum } \\
\text { Striatum }^{\mathrm{m}+}\end{array}$ & {$[141]$} \\
\hline & & $\begin{array}{c}\text { MPP + treated mice on } \\
\text { E-EPA diet }\end{array}$ & Striatum $^{+}$ & $\begin{array}{l}\text { cPLA2 } \\
\mathrm{COX} 2\end{array}$ & $\begin{array}{l}\text { Striatum } \\
\text { Striatum }^{\mathrm{m}+}\end{array}$ & [141] \\
\hline & & MPTP-treated mice & $\begin{array}{c}\text { Striatal } \\
\text { synaptoneurosomes }^{+}\end{array}$ & $\begin{array}{l}\text { cPLA2 } \\
\text { nNOS }\end{array}$ & $\begin{array}{l}\text { Striatum } \mathrm{p}^{+} \\
\text {Midbrain } \mathrm{p}^{+} \\
\text {Striatum }^{\mathrm{p}+} \\
\text { Midbrain }^{\mathrm{p}+}\end{array}$ & {$[142]$} \\
\hline & & MPTP-treated mice & $\begin{array}{l}\text { Midbrain } \\
\text { synaptoneurosomes }^{+}\end{array}$ & $\begin{array}{l}\text { cPLA2 } \\
\text { nNOS }\end{array}$ & $\begin{array}{l}\text { Striatum } \mathrm{p}^{\mathrm{p}} \\
\text { Midbrain }^{\mathrm{p}+} \\
\text { Striatum }^{\mathrm{p}+} \\
\text { Midbrain }\end{array}$ & {$[142]$} \\
\hline & DHA & PD postmortem tissue & $\mathrm{ACC}^{+}$ & F2-IsoP & $\mathrm{ACC}^{++}$ & [279] \\
\hline & DPA & PD postmortem tissue & $\mathrm{ACC}^{+}$ & F2-IsoP & $\mathrm{ACC}^{\mathrm{p}+}$ & {$[279]$} \\
\hline
\end{tabular}


Table 4. Cont.

\begin{tabular}{|c|c|c|c|c|c|c|}
\hline Class of Lipid & Lipids & $\begin{array}{c}\text { Mouse Models and } \\
\text { Human Patients with PD }\end{array}$ & $\begin{array}{l}\text { Source and } \\
\text { Level of Lipid }\end{array}$ & $\begin{array}{c}\text { Reactive } \\
\text { Oxygen Species }\end{array}$ & $\begin{array}{c}\text { Source and Level of } \\
\text { Reactive Oxygen Species }\end{array}$ & References \\
\hline Sphingolipid & GT1b & Sprague-Dawley rats & $\mathrm{SN}^{-}$ & iNOS & $\mathrm{SN}^{+}$ & [398] \\
\hline
\end{tabular}

Polyunsaturated fats (PUFA), prostaglandin (PGL), cardiolipin (CL), $\alpha$-linoleic acid ( $\alpha$-LA), arachidonic acid (ARA), docosahexaenoic acid (DHA), docosapentaenoic acid (DHA), ganglioside GT1b (GT1b), 6-hydroxydopamine (6-OHDA), knockout (KO), alpha-synuclein ( $\alpha$-syn), 1-methyl-4-phenylpyridinium (MPP), 1-methyl-4-phenyl-1,2,3,6-tetrahydropyridine (MPTP), eicosapentaenoic acid (EPA), Parkinson's disease (PD), hippocampus (Hipp), anterior cingulate cortex (ACC), substantia nigra (SN), isoprostane (IsoP), nitrous oxide (NOS), neuronal nitrous oxide (nNOS), cyclooxygenase (COX) and cytosolic phospholipase A (cPLA). Protein expression (p), mRNA expression $(\mathrm{m})$, high levels of expression $(+)$, and low levels of expression $(-)$.

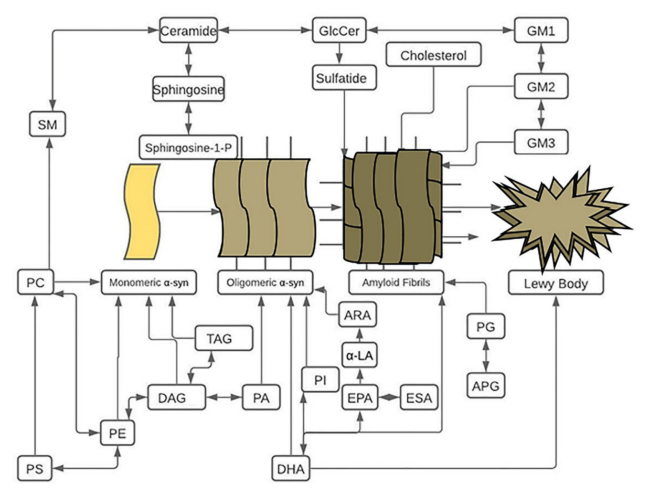

Figure 1. The different stages and lipids that affect alpha-synuclein ( $\alpha$-syn) aggregation into Lewy bodies (LBs). This chart depicts the overall relationships between lipids in this paper and their effects at different stages of LBs formation, not the exact conversions of one lipid to another. Black arrows indicate lipids that aid in the pathogenesis of PD. Phosphatidic acid (PA), phosphatidylcholine (PC), phosphatidylserine (PS), phosphatidylethanolamine (PE), phosphatidylinositol (PI), phosphatidylglycerol (PG), acylphosphatidylglycerol (APG), triacylglycerols (TAGs), diacylglycerols (DAGs), docosahexaenoic acid (DHA), $\alpha$-linoleic acid ( $\alpha$-LA), eicosapentaenoic acid (EPA), eicosatrienoic acid (ESA), arachidonic acid (ARA), sphingomyelin (SM), glucosylceramide (GluCer), gangliosides (GM), $\mathrm{P}$ (phosphorus).

\section{Conclusions}

Overall, the biological function of the lipid- $\alpha$-syn-cytokines-ROS pathway remains elusive; however, increasing evidence suggests that certain intracellular lipids and their impact on the induction of $\alpha$-syn abnormalities, excess generation of proinflammatory cytokines, and ROS are responsible for the propagation of brain inflammation in PD (Figure 1 and Tables 1-4). Several immune modulators, such as microglial cells and dopaminergic neuron expressions of CD1d, MHC I, and MHC II molecules, as well as increased brain infiltration of $\mathrm{T}$ cell subsets, including $\mathrm{CD}^{+} \mathrm{T}$ cells, $\mathrm{CD}^{+} \mathrm{T}$ cells, and NKT cells, and higher production of proinflammatory cytokines, have been observed in mouse models and human patients with PD [320-324]. Such T cells are known for activation of plasma B cells responsible for production of immunoglobulin G (IgG) and M (IgM) antibodies [399-402]. These antibodies are also responsible for the generation of proinflammatory cytokines in several diseases [163,287,403,404].

Interestingly, $\alpha$-syn-specific antibodies and excess generation of proinflammatory cytokines have been linked to the pathogenesis of PD [405-408]. On the basis of these findings, it is suggested that microglial cells and dopaminergic-neuron-mediated cellular take-up of lipids, (e.g., TAG, GPE, PA, PE, PC, GM1, GM2, and GM3) and/or such lipid-induced alteration in pathogenic forms of $\alpha$-syn (Figure 1), as well as their cellular processing and presentation by CD1d to NKT cells (for lipids) or presentation and delivery through MHC I/MHC II (for lipid-induced activated forms of $\alpha$-syn) to corresponding T 
cell subsets (e.g., $\mathrm{CD} 4^{+}$and $\mathrm{CD} 8^{+} \mathrm{T}$ cells) cause massive generation of proinflammatory cytokines, which is lethal in PD.

Furthermore, such lipid and/or lipid-induced activated $\alpha$-syn peptide processing and presentations trigger T-cell activation. These $\mathrm{T}$ cell subsets' interactions with resting $\mathrm{B}$ cells promote B-cell differentiation into plasma cells, which could lead to the generation of $\alpha$-syn-specific autoantibodies, which are all contribute to the development of chronic cellular and humoral immune inflammation, leading to neurodegeneration in PD.

Moreover, the prions, which are composed of self-propagating assemblies of a misfolded and/or aggregated $\alpha$-syn, initiate the fast seeding and spreading of these defected proteins throughout the peripheral and central nervous system in several animal and human models of synucleinopathies [57-67]. Some of the prion diseases have shown high accumulation of such defected proteins within the secondary lymphoid tissues of the host immune system as they make their journey from the site of infection to the brain [409]. Additionally, the gastrointestinal tissues, peripheral blood mononuclear cells and brain cells of PD patients have shown higher levels of $\alpha$-syn and its link to immune abnormalities $[18,410-416]$. It is therefore speculated that lipid- and cholesterol-mediated $\alpha$-syn aggregation and transmission mechanistically permit several of the brain residential cells, i.e., microglial cells, neurons, and infiltrated immune cells, (e.g., $\mathrm{T}$ or B cells) to cause excessive processing and presentation of defected $\alpha$-syn in PD. Such $\alpha$-syn-mediated joint action of neurological and immunological cells fuels massive generation of proinflammatory cytokines and autoantibodies specific to $\alpha$-syn, which eventually spark severe and chronic neuroinflammation and neurodegeneration in PD. However, the precise molecular mechanism(s) by which different lipids and/or such lipid-induced $\alpha$-syn abnormalities might potentially lead to multiple strains of abnormal and/or prion-like $\alpha$-syn, which might account for clinical heterogeneity and cause activation of cellular and humoral immune reactions that lead to the development of brain inflammation and neurodegeneration in $\mathrm{PD}$, remains undetermined and needs further study. As the gold standard of treatment for PD, levodopa and its derivatives are only the standard care for PD patients [417]. However, such therapies do not alter the disease's course, and nor do they stop or reverse the brain inflammation, which often has the greatest impact on quality of life [418,419]. Additionally, the long-term use of these drugs has been linked to several adverse effects, such as fluctuations, dyskinesia, toxicity, or loss of efficacy [420]. The relationships between these lipid and $\alpha$-syn interactions open new areas of research that may identify several of the lipids, $\alpha$-syn-specific antibodies and their receptors, proinflammatory cytokines and their receptors, and interesting anti-inflammatory therapies for PD and other synucleinopathies.

Author Contributions: Conceptualization, M.K.P.; resources, M.K.P.; data curation, S.L.H.; writingoriginal draft preparation, M.K.P.; writing—review and editing, M.K.P.; visualization, M.K.P. and S.L.H.; supervision, M.K.P.; project administration, M.K.P.; funding acquisition, M.K.P. All authors have read and agreed to the published version of the manuscript.

Funding: This research received no external funding.

Institutional Review Board Statement: Not applicable.

Informed Consent Statement: Not applicable.

Data Availability Statement: Not applicable.

Acknowledgments: This work was supported by Division of Human Genetics, Cincinnati Children's Hospital Medical Center (Cincinnati, OH, USA) and Michael J. Fox Foundation (New YORK, NY, USA) to MKP. We would like to acknowledge Albert F Magnusen and Charles D Loftice for office and laboratory support.

Conflicts of Interest: The authors declare that the research was conducted in the absence of any commercial or financial relationships that could be construed as a potential conflict of interest. 


\section{References}

1. Tysnes, O.-B.; Storstein, A. Epidemiology of Parkinson's disease. J. Neural Transm. 2017, 124, 901-905. [CrossRef]

2. Marras, C.; Beck, J.C.; Bower, J.H.; Roberts, E.; Ritz, B.; Ross, G.W.; Abbott, R.D.; Savica, R.; Van den Eeden, S.K.; Willis, A.W.; et al. Prevalence of Parkinson's disease across North America. NPJ Parkinson's Dis. 2018, 4, 21. [CrossRef] [PubMed]

3. Wakabayashi, K.; Tanji, K.; Mori, F.; Takahashi, H. The Lewy body in Parkinson's disease: Molecules implicated in the formation and degradation of $\alpha$-synuclein aggregates. Neuropathology 2007, 27, 494-506. [CrossRef] [PubMed]

4. Wakabayashi, K.; Tanji, K.; Odagiri, S.; Miki, Y.; Mori, F.; Takahashi, H. The Lewy Body in Parkinson's Disease and Related Neurodegenerative Disorders. Mol. Neurobiol. 2012, 47, 495-508. [CrossRef] [PubMed]

5. Chen, X.; Feng, W.; Ou, R.; Liu, J.; Yang, J.; Fu, J.; Cao, B.; Chen, Y.; Wei, Q.; Shang, H. Evidence for Peripheral Immune Activation in Parkinson's Disease. Front. Aging Neurosci. 2021, 13. [CrossRef]

6. Cao, J.-J.; Li, K.-S.; Shen, Y.-Q. Activated Immune Cells in Parkinson's Disease. J. Neuroimmune Pharmacol. $2011,6,323-329$. [CrossRef]

7. Clark, L.F.; Kodadek, T. The Immune System and Neuroinflammation as Potential Sources of Blood-Based Biomarkers for Alzheimer's Disease, Parkinson's Disease, and Huntington's Disease. ACS Chem. Neurosci. 2016, 7, 520-527. [CrossRef]

8. Jayaram, S.; Krishnamurthy, P.T. Role of microgliosis, oxidative stress and associated neuroinflammation in the pathogenesis of Parkinson's disease: The therapeutic role of Nrf2 activators. Neurochem. Int. 2021, 145, 105014. [CrossRef]

9. Qian, L.; Flood, P.M. Microglial cells and Parkinson's disease. Immunol. Res. 2008, 41, 155-164. [CrossRef]

10. Jenner, P. Oxidative stress in Parkinson's disease. Ann. Neurol. 2003, 53 (Suppl. S3), S26-S38. [CrossRef]

11. Wei, Z.; Li, X.; Li, X.; Liu, Q.; Cheng, Y. Oxidative Stress in Parkinson's Disease: A Systematic Review and Meta-Analysis. Front. Mol. Neurosci. 2018, 11, 236. [CrossRef]

12. Jiang, T.; Li, G.; Xu, J.; Gao, S.; Chen, X. The Challenge of the Pathogenesis of Parkinson's Disease: Is Autoimmunity the Culprit? Front. Immunol. 2018, 9, 2047. [CrossRef] [PubMed]

13. Bonam, S.R.; Muller, S. Parkinson's disease is an autoimmune disease: A reappraisal. Autoimmun. Rev. 2020, 19, 102684. [CrossRef] [PubMed]

14. Hirsch, E.C.; Vyas, S.; Hunot, S. Neuroinflammation in Parkinson's disease. Park. Relat. Disord. 2012, 18, S210-S212. [CrossRef]

15. Balestrino, R.; Schapira, A.H.V. Parkinson disease. Eur. J. Neurol. 2020, 27, 27-42. [CrossRef] [PubMed]

16. Xia, R.; Mao, Z.-H. Progression of motor symptoms in Parkinson's disease. Neurosci. Bull. 2012, 28, 39-48. [CrossRef] [PubMed]

17. Poewe, W. Non-motor symptoms in Parkinson's disease. Eur. J. Neurol. 2008, 15 (Suppl. S1), 14-20. [CrossRef]

18. Magnusen, A.F.; Hatton, S.L.; Rani, R.; Pandey, M.K. Genetic Defects and Pro-inflammatory Cytokines in Parkinson's Disease. Front. Neurol. 2021, 12, Review. [CrossRef]

19. Klein, C.; Westenberger, A. Genetics of Parkinson's Disease. Cold Spring Harb. Perspect. Med. 2012, 2, a008888. [CrossRef]

20. Sidransky, E.; Lopez, G. The link between the GBA gene and parkinsonism. Lancet Neurol. 2012, 11, 986-998. [CrossRef]

21. Li, Y.; Li, P.; Liang, H.; Zhao, Z.; Hashimoto, M.; Wei, J. Gaucher-Associated Parkinsonism. Cell. Mol. Neurobiol. $2015,35,755-761$. [CrossRef]

22. Westbroek, W.; Gustafson, A.M.; Sidransky, E. Exploring the link between glucocerebrosidase mutations and parkinsonism Trends Mol. Med. 2011, 17, 485-493. [CrossRef]

23. Migdalska-Richards, A.; Schapira, A.H.V. The relationship between glucocerebrosidase mutations and Parkinson disease. $J$. Neurochem. 2016, 139, 77-90. [CrossRef]

24. Gispert, S.; del Turco, D.; Garrett, L.; Chen, A.; Bernard, D.J.; Hamm-Clement, J.; Korf, H.-W.; Deller, T.; Braak, H.; Auburger, G.; et al. Transgenic mice expressing mutant A53T human alpha-synuclein show neuronal dysfunction in the absence of aggregate formation. Mol. Cell. Neurosci. 2003, 24. [CrossRef]

25. Murphy, K.E.; Gysbers, A.M.; Abbott, S.K.; Tayebi, N.; Kim, W.S.; Sidransky, E.; Cooper, A.; Garner, B.; Halliday, G.M. Reduced glucocerebrosidase is associated with increased $\alpha$-synuclein in sporadic Parkinson's disease. Brain 2014, 137, 834-848. [CrossRef] [PubMed]

26. Bae, E.-J.; Yang, N.Y.; Lee, C.; Lee, H.-J.; Kim, S.; Sardi, S.P.; Lee, S.-J. Loss of glucocerebrosidase 1 activity causes lysosomal dysfunction and $\alpha$-synuclein aggregation. Exp. Mol. Med. 2015, 47, e188. [CrossRef] [PubMed]

27. Kong, B.; Yang, T.; Gu, J.W.; Kuang, Y.Q.; Cheng, L.; Yang, W.T.; Yang, X.K.; Xia, X.; Cheng, J.M.; Ma, Y.; et al. The association between lysosomal protein glucocerebrosidase and Parkinson's disease. Eur. Rev. Med. Pharmacol. Sci. 2013, 17, $143-151$.

28. Parnetti, L.; Chiasserini, D.; Persichetti, E.; Eusebi, P.; Varghese, S.; Msc, M.M.Q.; Dardis, A.; Deganuto, M.; de Carlo, C.; Castrioto, A.; et al. Cerebrospinal fluid lysosomal enzymes and alpha-synuclein in Parkinson's disease. Mov. Disord. 2014, 29, 1019-1027. [CrossRef] [PubMed]

29. Rothaug, M.; Zunke, F.; Mazzulli, J.R.; Schweizer, M.; Altmeppen, H.; Lüllmann-Rauch, R.; Kallemeijn, W.W.; Gaspar, P.J.M.D.S.; Aerts, J.; Glatzel, M.; et al. LIMP-2 expression is critical for -glucocerebrosidase activity and alpha-synuclein clearance. Proc. Natl. Acad. Sci. USA 2014, 111, 15573-15578. [CrossRef]

30. Senkevich, K.A.; Kopytova, A.E.; Usenko, T.S.; Emelyanov, A.K.; Pchelina, S.N. Parkinson's Disease Associated with GBA Gene Mutations: Molecular Aspects and Potential Treatment Approaches. Acta Naturae 2021, 13, 70-78. [CrossRef] [PubMed]

31. Belarbi, K.; Cuvelier, E.; Bonte, M.-A.; Desplanque, M.; Gressier, B.; Devos, D.; Chartier-Harlin, M.-C. Glycosphingolipids and neuroinflammation in Parkinson's disease. Mol. Neurodegener. 2020, 15, 1-16. [CrossRef] 
32. Avisar, H.; Guardia-Laguarta, C.; Area-Gomez, E.; Surface, M.; Chan, A.K.; Alcalay, R.N.; Lerner, B. Lipidomics Prediction of Parkinson's Disease Severity: A Machine-Learning Analysis. J. Park. Dis. 2021, 11, 1141-1155. [CrossRef]

33. Fanning, S.; Selkoe, D.; Dettmer, U. Parkinson's disease: Proteinopathy or lipidopathy? Npj Park. Dis. 2020, 6, 1-9. [CrossRef]

34. Castellanos, D.B.; Martín-Jiménez, C.A.; Rojas-Rodríguez, F.; Barreto, G.E.; González, J. Brain lipidomics as a rising field in neurodegenerative contexts: Perspectives with Machine Learning approaches. Front. Neuroendocr. 2021, 61, 100899. [CrossRef]

35. Klemann, C.J.H.M.; Martens, G.J.M.; Sharma, M.; Martens, M.B.; Isacson, O.; Gasser, T.; Visser, J.E.; Poelmans, G. Integrated molecular landscape of Parkinson's disease. Npj Park. Dis. 2017, 3, 1-7. [CrossRef] [PubMed]

36. Conway, K.A.; Harper, J.D.; Lansbury, P.T. Accelerated in vitro fibril formation by a mutant $\alpha$-synuclein linked to early-onset Parkinson disease. Nat. Med. 1998, 4, 1318-1320. [CrossRef] [PubMed]

37. Spillantini, M.G.; Divane, A.; Goedert, M. Assignment of Human $\alpha$-Synuclein (SNCA) and $\beta$-Synuclein (SNCB) Genes to Chromosomes 4q21 and 5q35. Genomics 1995, 27, 379-381. [CrossRef] [PubMed]

38. Maroteaux, L.; Campanelli, J.T.; Scheller, R.H. Synuclein: A neuron-specific protein localized to the nucleus and presynaptic nerve terminal. J. Neurosci. 1988, 8, 2804-2815. [CrossRef]

39. Murphy, D.D.; Rueter, S.M.; Trojanowski, J.Q.; Lee, V.M.-Y. Synucleins Are Developmentally Expressed, and $\alpha$-Synuclein Regulates the Size of the Presynaptic Vesicular Pool in Primary Hippocampal Neurons. J. Neurosci. 2000, 20, 3214-3220. [CrossRef]

40. Scott, D.; Roy, S. $\alpha$-Synuclein Inhibits Intersynaptic Vesicle Mobility and Maintains Recycling-Pool Homeostasis. J. Neurosci. 2012, 32, 10129-10135. [CrossRef]

41. Burré, J.; Sharma, M.; Tsetsenis, T.; Buchman, V.; Etherton, M.R.; Südhof, T.C. $\alpha$-Synuclein Promotes SNARE-Complex Assembly in Vivo and in Vitro. Science 2010, 329, 1663-1667. [CrossRef] [PubMed]

42. Nemani, V.M.; Lu, W.; Berge, V.; Nakamura, K.; Onoa, B.; Lee, M.K.; Chaudhry, F.A.; Nicoll, R.A.; Edwards, R.H. Increased Expression of $\alpha$-Synuclein Reduces Neurotransmitter Release by Inhibiting Synaptic Vesicle Reclustering after Endocytosis. Neuron 2010, 65, 66-79. [CrossRef] [PubMed]

43. Jo, E.; McLaurin, J.; Yip, C.M.; George-Hyslop, P.S.; Fraser, P.E. $\alpha$-Synuclein Membrane Interactions and Lipid Specificity. J. Biol. Chem. 2000, 275, 34328-34334. [CrossRef]

44. Van Rooijen, B.D.; van Leijenhorst-Groener, K.A.; Claessens, M.M.; Subramaniam, V. Tryptophan Fluorescence Reveals Structural Features of $\alpha$-Synuclein Oligomers. J. Mol. Biol. 2009, 394, 826-833. [CrossRef] [PubMed]

45. Lee, S.-J.; Desplats, P.; Sigurdson, C.; Tsigelny, I.; Masliah, E. Cell-to-cell transmission of non-prion protein aggregates. Nat. Rev. Neurol. 2010, 6, 702-706. [CrossRef]

46. McCann, H.; Stevens, C.H.; Cartwright, H.; Halliday, G.M. alpha-Synucleinopathy phenotypes. Parkinsonism Relat. Disord. 2014, 20 (Suppl. S1), S62-S67. [CrossRef]

47. Li, J.-Y.; Englund, E.; Holton, J.L.; Soulet, D.; Hagell, P.; Lees, A.J.; Lashley, T.; Quinn, N.P.; Rehncrona, S.; Björklund, A.; et al Lewy bodies in grafted neurons in subjects with Parkinson's disease suggest host-to-graft disease propagation. Nat. Med. 2008, 14, 501-503. [CrossRef]

48. Kordower, J.H.; Chu, Y.; Hauser, R.A.; Freeman, T.B.; Olanow, C.W. Lewy body-like pathology in long-term embryonic nigral transplants in Parkinson's disease. Nat. Med. 2008, 14, 504-506. [CrossRef]

49. Gorodinsky, A.; Harris, D.A. Glycolipid-anchored proteins in neuroblastoma cells form detergent-resistant complexes without caveolin. J. Cell Biol. 1995, 129, 619-627. [CrossRef]

50. Puig, B.; Altmeppen, H.; Glatzel, M. The GPI-anchoring of PrP. Prion 2014, 8, 11-18. [CrossRef]

51. Baldwin, M.A. Analysis of Glycosylphosphatidylinositol Protein Anchors: The Prion Protein. Methods Enzymol. 2005, 405, 172-187. [CrossRef]

52. Latarjet, R.; Muel, B.; Haig, D.A.; Clarke, M.C.; Alper, T. Inactivation of the Scrapie Agent by Near Monochromatic Ultraviolet Light. Nature 1970, 227, 1341-1343. [CrossRef]

53. Wang, F.; Ma, J. Role of lipid in forming an infectious prion? Acta Biochim. Biophys. Sin. 2013, 45, 485-493. [CrossRef]

54. Kim, C.; Xiao, X.; Chen, S.; Haldiman, T.; Smirnovas, V.; Kofskey, D.; Warren, M.; Surewicz, K.; Maurer, N.R.; Kong, Q.; et al. Artificial strain of human prions created in vitro. Nat. Commun. 2018, 9, 1-11. [CrossRef]

55. Taraboulos, A.; Scott, M.; Semenov, A.; Avrahami, D.; Laszlo, L.; Prusiner, S.B. Cholesterol depletion and modification of $\mathrm{COOH}$-terminal targeting sequence of the prion protein inhibit formation of the scrapie isoform [published erratum appears in J Cell Biol 1995 Jul;130(2):501]. J. Cell Biol. 1995, 129, 121-132. [CrossRef] [PubMed]

56. Deleault, N.R.; Kascsak, R.; Geoghegan, J.C.; Supattapone, S. Species-Dependent Differences in Cofactor Utilization for Formation of the Protease-Resistant Prion Protein in Vitro. Biochemistry 2010, 49, 3928-3934. [CrossRef] [PubMed]

57. Aulic, S.; Masperone, L.; Narkiewicz, J.; Isopi, E.; Bistaffa, E.; Ambrosetti, E.; Pastore, B.; de Cecco, E.; Scaini, D.; Zago, P.; et al $\alpha$-Synuclein Amyloids Hijack Prion Protein to Gain Cell Entry, Facilitate Cell-to-Cell Spreading and Block Prion Replication. Sci. Rep. 2017, 7, 1-12. [CrossRef] [PubMed]

58. Desplats, P.; Lee, H.-J.; Bae, E.-J.; Patrick, C.; Rockenstein, E.; Crews, L.; Spencer, B.; Masliah, E.; Lee, S.-J. Inclusion formation and neuronal cell death through neuron-to-neuron transmission of $\alpha$-synuclein. Proc. Natl. Acad. Sci. USA 2009, 106, 13010-13015. [CrossRef] [PubMed]

59. Luk, K.C.; Song, C.; O’Brien, P.; Stieber, A.; Branch, J.R.; Brunden, K.R.; Trojanowski, J.Q.; Lee, V.M.-Y. Exogenous alpha-synuclein fibrils seed the formation of Lewy body-like intracellular inclusions in cultured cells. Proc. Natl. Acad. Sci. USA 2009, 106, 20051-20056. [CrossRef] 
60. Prusiner, S.B.; Woerman, A.L.; Mordes, D.A.; Watts, J.C.; Rampersaud, R.; Berry, D.B.; Patel, S.; Oehler, A.; Lowe, J.K.; Kravitz, S.N.; et al. Evidence for $\alpha$-synuclein prions causing multiple system atrophy in humans with parkinsonism. Proc. Natl. Acad. Sci. USA 2015, 112, E5308-E5317. [CrossRef]

61. Van den Berge, N.; Ferreira, N.; Gram, H.; Mikkelsen, T.W.; Alstrup, A.K.O.; Casadei, N.; Tsung-Pin, P.; Riess, O.; Nyengaard, J.R.; Tamgüney, G.; et al. Evidence for bidirectional and trans-synaptic parasympathetic and sympathetic propagation of alphasynuclein in rats. Acta Neuropathol. 2019, 138, 535-550. [CrossRef]

62. Ferreira, N.; Gram, H.; Sorrentino, Z.A.; Gregersen, E.; Schmidt, S.I.; Reimer, L.; Betzer, C.; Perez-Gozalbo, C.; Beltoja, M.; Nagaraj, M.; et al. Multiple system atrophy-associated oligodendroglial protein p25 $\alpha$ stimulates formation of novel $\alpha$-synuclein strain with enhanced neurodegenerative potential. Acta Neuropathol. 2021, 142, 87-115. [CrossRef]

63. Irwin, D.; Lee, V.M.-Y.; Trojanowski, J.Q. Parkinson's disease dementia: Convergence of $\alpha$-synuclein, tau and amyloid- $\beta$ pathologies. Nat. Rev. Neurosci. 2013, 14, 626-636. [CrossRef] [PubMed]

64. Lau, A.; So, R.W.L.; Lau, H.H.C.; Sang, J.C.; Ruiz-Riquelme, A.; Fleck, S.C.; Stuart, E.; Menon, S.; Visanji, N.P.; Meisl, G.; et al. $\alpha$-Synuclein strains target distinct brain regions and cell types. Nat. Neurosci. 2019, 23, 21-31. [CrossRef]

65. Jan, A.; Gonçalves, N.P.; Vaegter, C.B.; Jensen, P.H.; Ferreira, N. The Prion-Like Spreading of Alpha-Synuclein in Parkinson's Disease: Update on Models and Hypotheses. Int. J. Mol. Sci. 2021, 22, 8338. [CrossRef]

66. Ferreira, N.; Gonçalves, N.P.; Jan, A.; Jensen, N.M.; van der Laan, A.; Mohseni, S.; Vægter, C.B.; Jensen, P.H. Trans-synaptic spreading of alpha-synuclein pathology through sensory afferents leads to sensory nerve degeneration and neuropathic pain Acta Neuropathol. Commun. 2021, 9, 1-17. [CrossRef] [PubMed]

67. Berge, N.V.D.; Ferreira, N.; Mikkelsen, T.W.; Alstrup, A.K.O.; Tamgüney, G.; Karlsson, P.; Terkelsen, A.J.; Nyengaard, J.R.; Jensen, P.H.; Borghammer, P. Ageing promotes pathological alpha-synuclein propagation and autonomic dysfunction in wild-type rats. Brain 2021, 144, 1853-1868. [CrossRef] [PubMed]

68. Ma, J.; Gao, J.; Wang, J.; Xie, A. Prion-Like Mechanisms in Parkinson's Disease. Front. Neurosci. 2019, 13, 552. [CrossRef]

69. Uversky, V.N. Neuropathology, biochemistry, and biophysics of alpha-synuclein aggregation. J. Neurochem. 2007, 103, 17-37. [CrossRef]

70. Varkey, J.; Isas, J.M.; Mizuno, N.; Jensen, M.B.; Bhatia, V.K.; Jao, C.C.; Petrlova, J.; Voss, J.C.; Stamou, D.G.; Steven, A.C.; et al. Membrane Curvature Induction and Tubulation Are Common Features of Synucleins and Apolipoproteins. J. Biol. Chem. 2010, 285, 32486-32493. [CrossRef]

71. Mori, A.; Imai, Y.; Hattori, N. Lipids: Key Players That Modulate $\alpha$-Synuclein Toxicity and Neurodegeneration in Parkinson's Disease. Int. J. Mol. Sci. 2020, 21, 3301. [CrossRef]

72. Kim, W.S.; Kågedal, K.; Halliday, G.M. Alpha-synuclein biology in Lewy body diseases. Alzheimer's Res. Ther. 2014, 6, 73. [CrossRef]

73. Esposito, E.; di Matteo, V.; di Giovanni, G. Death in the substantia nigra: A motor tragedy. Expert Rev. Neurother. 2007, 7, 677-697. [CrossRef]

74. Reish, H.E.A.; Standaert, D.G. Role of $\alpha$-Synuclein in Inducing Innate and Adaptive Immunity in Parkinson Disease. J. Park. Dis. 2015, 5, 1-19. [CrossRef]

75. Jenco, J.M.; Rawlingson, A.; Daniels, A.B.; Morris, A.J. Regulation of Phospholipase D2: Selective Inhibition of Mammalian Phospholipase D Isoenzymes by $\alpha$ - and $\beta$-Synucleins. Biochemistry 1998, 37, 4901-4909. [CrossRef]

76. Payton, J.E.; Perrin, R.J.; Woods, W.S.; George, J.M. Structural Determinants of PLD2 Inhibition by $\alpha$-Synuclein. J. Mol. Biol. 2004, 337, 1001-1009. [CrossRef] [PubMed]

77. Castagnet, P.I.; Golovko, M.Y.; Barceló-Coblijn, G.C.; Nussbaum, R.L.; Murphy, E.J. Fatty acid incorporation is decreased in astrocytes cultured from $\alpha$-synuclein gene-ablated mice. J. Neurochem. 2005, 94, 839-849. [CrossRef]

78. Golovko, M.; Faergeman, .N.J.; Cole, .N.B.; Castagnet, .P.I.; Nussbaum, .A.R.L.; Murphy, .E.J. $\alpha$-Synuclein Gene Deletion Decreases Brain Palmitate Uptake and Alters the Palmitate Metabolism in the Absence of $\alpha$-Synuclein Palmitate Binding. Biochemistry 2005, 44, 8251-8259. [CrossRef] [PubMed]

79. Narayanan, V.; Guo, Y.; Scarlata, S. Fluorescence Studies Suggest a Role for $\alpha$-Synuclein in the Phosphatidylinositol Lipid Signaling Pathway. Biochemistry 2004, 44, 462-470. [CrossRef]

80. Barceló-Coblijn, G.; Golovko, M.; Weinhofer, I.; Berger, J.; Murphy, E.J. Brain neutral lipids mass is increased in $\alpha$-synuclein gene-ablated mice. J. Neurochem. 2006, 101, 132-141. [CrossRef] [PubMed]

81. Sharon, R.; Bar-Joseph, I.; Frosch, M.P.; Walsh, D.M.; Hamilton, J.A.; Selkoe, D.J. The Formation of Highly Soluble Oligomers of $\alpha$-Synuclein Is Regulated by Fatty Acids and Enhanced in Parkinson's Disease. Neuron 2003, 37, 583-595. [CrossRef]

82. Perez, R.G.; Waymire, J.C.; Lin, E.; Liu, J.J.; Guo, F.; Zigmond, M.J. A Role for $\alpha$-Synuclein in the Regulation of Dopamine Biosynthesis. J. Neurosci. 2002, 22, 3090-3099. [CrossRef] [PubMed]

83. Pfefferkorn, C.M.; Jiang, Z.; Lee, J.C. Biophysics of $\alpha$-synuclein membrane interactions. Biochim. Biophys. Acta (BBA)—Biomembr. 2012, 1818, 162-171. [CrossRef] [PubMed]

84. Ostrerova-Golts, N.; Petrucelli, L.; Hardy, J.; Lee, J.M.; Farrer, M.; Wolozin, B. The A53T $\alpha$-Synuclein Mutation Increases Iron-Dependent Aggregation and Toxicity. J. Neurosci. 2000, 20, 6048-6054. [CrossRef] [PubMed]

85. Markopoulou, K.; Dickson, D.W.; McComb, R.D.; Wszolek, Z.K.; Katechalidou, L.; Avery, L.; Stansbury, M.S.; Chase, B.A. Clinical, neuropathological and genotypic variability in SNCA A53T familial Parkinson's disease. Variability in familial Parkinson's disease. Acta Neuropathol. 2008, 116, 25-35. [CrossRef] 
86. Gispert, S.; Brehm, N.; Weil, J.; Seidel, K.; Rüb, U.; Kern, B.; Walter, M.; Roeper, J.; Auburger, G. Potentiation of neurotoxicity in double-mutant mice with Pink1 ablation and A53T-SNCA overexpression. Hum. Mol. Genet. 2014, 24, 1061-1076. [CrossRef] [PubMed]

87. Alecu, I.; Bennett, S.A.L. Dysregulated Lipid Metabolism and Its Role in $\alpha$-Synucleinopathy in Parkinson's Disease. Front. Neurosci. 2019, 13, 328. [CrossRef]

88. Browning, J.D.; Szczepaniak, L.S.; Dobbins, R.; Nuremberg, P.; Horton, J.D.; Cohen, J.C.; Grundy, S.M.; Hobbs, H.H. Prevalence of hepatic steatosis in an urban population in the United States: Impact of ethnicity. Hepatology 2004, 40, $1387-1395$. [CrossRef] [PubMed]

89. Berglund, L.; Brunzell, J.D.; Goldberg, A.C.; Goldberg, I.J.; Sacks, F.M.; Murad, M.H.; Stalenhoef, A.F.H. Evaluation and Treatment of Hypertriglyceridemia: An Endocrine Society Clinical Practice Guideline. J. Clin. Endocrinol. Metab. 2012, 97, $2969-2989$. [CrossRef]

90. Ford, E.S.; Li, C.; Zhao, G.; Pearson, W.S.; Mokdad, A.H. Hypertriglyceridemia and Its Pharmacologic Treatment Among US Adults. Arch. Intern. Med. 2009, 169, 572-578. [CrossRef] [PubMed]

91. Bodnar, L.M.; Ness, R.B.; Harger, G.F.; Roberts, J.M. Inflammation and Triglycerides Partially Mediate the Effect of Prepregnancy Body Mass Index on the Risk of Preeclampsia. Am. J. Epidemiol. 2005, 162, 1198-1206. [CrossRef] [PubMed]

92. Johansen, M.; Vedel-Krogh, S.; Nielsen, S.F.; Afzal, S.; Smith, G.D.; Nordestgaard, B.G. Per-Particle Triglyceride-Rich Lipoproteins Imply Higher Myocardial Infarction Risk Than Low-Density Lipoproteins: Copenhagen General Population Study. Arter. Thromb. Vasc. Biol. 2021, 41, 2063-2075. [CrossRef] [PubMed]

93. Jeppesen, J.; Hein, H.O.; Suadicani, P.; Gyntelberg, F. High Triglycerides and Low HDL Cholesterol and Blood Pressure and Risk of Ischemic Heart Disease. Hypertension 2000, 36, 226-232. [CrossRef] [PubMed]

94. Scherer, J.; Singh, V.P.; Pitchumoni, C.S.; Yadav, D. Issues in Hypertriglyceridemic Pancreatitis: An Up-date. J. Clin. Gastroenterol. 2014, 48, 195-203. [CrossRef] [PubMed]

95. Meng, X.; Yan, J.; Ma, J.; Na Kang, A.; Kang, S.Y.; Zhang, Q.; Lyu, C.; Park, Y.-K.; Jung, H.W.; Zhang, S. Effects of Jowiseungki-tang on high fat diet-induced obesity in mice and functional analysis on network pharmacology and metabolomics analysis. $J$. Ethnopharmacol. 2021, 283, 114700. [CrossRef]

96. Park, B.; Lee, H.S.; Lee, Y.-J. Triglyceride glucose (TyG) index as a predictor of incident type 2 diabetes among nonobese adults: A 12-year longitudinal study of the Korean Genome and Epidemiology Study cohort. Transl. Res. 2020, 228, 42-51. [CrossRef]

97. Cole, N.B.; Murphy, D.D.; Grider, T.; Rueter, S.; Brasaemle, D.; Nussbaum, R.L. Lipid Droplet Binding and Oligomerization Properties of the Parkinson's Disease Protein $\alpha$-Synuclein. J. Biol. Chem. 2002, 277, 6344-6352. [CrossRef] [PubMed]

98. Campos, S.S.; Alza, N.P.; Salvador, G.A. Lipid metabolism alterations in the neuronal response to A53T $\alpha$-synuclein and Fe-induced injury. Arch. Biochem. Biophys. 2018, 655, 43-54. [CrossRef] [PubMed]

99. Sääksjärvi, K.; Knekt, P.; Männistö, S.; Lyytinen, J.; Heliövaara, M. Prospective study on the components of metabolic syndrome and the incidence of Parkinson's disease. Park. Relat. Disord. 2015, 21, 1148-1155. [CrossRef]

100. He, Q.; Wang, M.; Petucci, C.; Gardell, S.J.; Han, X. Rotenone induces reductive stress and triacylglycerol deposition in C2C12 cells. Int. J. Biochem. Cell Biol. 2013, 45, 2749-2755. [CrossRef]

101. Taylor-Robinson, S.D.; Sargentoni, J.; Bell, J.D.; Thomas, E.L.; Marcus, C.D.; Changani, K.K.; Saeed, N.; Hodgson, H.J.F.; Davidson, B.R.; Burroughs, A.K.; et al. In vivo and in vitro hepatic phosphorus-31 magnetic resonance spectroscopy and electron microscopy in chronic ductopenic rejection of human liver allografts. Gut 1998, 42, 735-743. [CrossRef] [PubMed]

102. Van Der Kemp, W.J.M.; Stehouwer, B.L.; Runge, J.H.; Wijnen, J.P.; Nederveen, A.J.; Luijten, P.R.; Klomp, D.W.J. Glycerophosphocholine and Glycerophosphoethanolamine Are Not the Main Sources of the In Vivo31P MRS Phosphodiester Signals from Healthy Fibroglandular Breast Tissue at 7 T. Front. Oncol. 2016, 6. [CrossRef] [PubMed]

103. Blusztajn, J.K.; Gonzalez-Coviella, I.L.; Logue, M.; Growdon, J.H.; Wurtman, R.J. Levels of phospholipid catabolic intermediates, glycerophosphocholine and glycerophosphoethanolamine, are elevated in brains of Alzheimer's disease but not of Down's syndrome patients. Brain Res. 1990, 536, 240-244. [CrossRef]

104. Zakharov, S.D.; Hulleman, J.D.; Dutseva, E.A.; Antonenko, Y.N.; Rochet, J.-C.; Cramer, W.A. Helical $\alpha$-Synuclein Forms Highly Conductive Ion Channels. Biochemistry 2007, 46, 14369-14379. [CrossRef]

105. Yu, C.; Chen, Y.; Cline, G.W.; Zhang, D.; Zong, H.; Wang, Y.; Bergeron, R.; Kim, J.K.; Cushman, S.W.; Cooney, G.J.; et al. Mechanism by Which Fatty Acids Inhibit Insulin Activation of Insulin Receptor Substrate-1 (IRS-1)-associated Phosphatidylinositol 3-Kinase Activity in Muscle. J. Biol. Chem. 2002, 277, 50230-50236. [CrossRef]

106. Griffin, M.E.; Marcucci, M.J.; Cline, G.W.; Bell, K.; Barucci, N.; Lee, D.; Goodyear, L.J.; Kraegen, E.W.; White, M.F.; Shulman, G.I. Free fatty acid-induced insulin resistance is associated with activation of protein kinase $\mathrm{C}$ theta and alterations in the insulin signaling cascade. Diabetes 1999, 48, 1270-1274. [CrossRef]

107. Erion, D.M.; Shulman, G.I. Diacylglycerol-mediated insulin resistance. Nat. Med. 2010, 16, 400-402. [CrossRef]

108. Evangelisti, C.; Bortul, R.; Tabellini, G.; Papa, V.; Cocco, L.; Martelli, A.M. Nuclear expression of diacyl-glycerol kinases: Possible involvement in DNA replication. Eur. J. Histochem. 2006, 50, 9-13.

109. Soste, M.; Charmpi, K.; Lampert, F.; Gerez, J.A.; van Oostrum, M.; Malinovska, L.; Boersema, P.J.; Prymaczok, N.C.; Riek, R.; Peter, M.; et al. Proteomics-Based Monitoring of Pathway Activity Reveals that Blocking Diacylglycerol Biosynthesis Rescues from Alpha-Synuclein Toxicity. Cell Syst. 2019, 9, 309-320.e8. [CrossRef] 
110. Wood, P.L.; Tippireddy, S.; Feriante, J.; Woltjer, R.L. Augmented frontal cortex diacylglycerol levels in Parkinson's disease and Lewy Body Disease. PLoS ONE 2018, 13, e0191815. [CrossRef]

111. Buckley, M.T.; Racimo, F.; Allentoft, M.E.; Jensen, M.K.; Jonsson, A.; Huang, H.; Hormozdiari, F.; Sikora, M.; Marnetto, D.; Eskin, E.; et al. Selection in Europeans on Fatty Acid Desaturases Associated with Dietary Changes. Mol. Biol. Evol. 2017, 34, 1307-1318. [CrossRef] [PubMed]

112. Fecchio, C.; Palazzi, L.; de Laureto, P.P. $\alpha$-Synuclein and Polyunsaturated Fatty Acids: Molecular Basis of the Interaction and Implication in Neurodegeneration. Molecules 2018, 23, 1531. [CrossRef] [PubMed]

113. Marszalek, J.R.; Lodish, H.F. Docosahexaenoic acid, fatty acid-interacting proteins, and neuronal function: Breastmilk and Fish Are Good for You. Annu. Rev. Cell Dev. Biol. 2005, 21, 633-657. [CrossRef]

114. Darios, F.; Davletov, B. Omega-3 and omega- 6 fatty acids stimulate cell membrane expansion by acting on syntaxin 3 . Nature 2006, 440, 813-817. [CrossRef] [PubMed]

115. Mathias, R.A.; Fu, W.; Akey, J.M.; Ainsworth, H.C.; Torgerson, D.G.; Ruczinski, I.; Sergeant, S.; Barnes, K.C.; Chilton, F.H. Adaptive Evolution of the FADS Gene Cluster within Africa. PLoS ONE 2012, 7, e44926. [CrossRef]

116. Hester, A.G.; Murphy, R.C.; Uhlson, C.J.; Ivester, P.; Lee, T.C.; Sergeant, S.; Miller, L.R.; Howard, T.D.; Mathias, R.A.; Chilton, F.H. Relationship between a Common Variant in the Fatty Acid Desaturase (FADS) Cluster and Eicosanoid Generation in Humans. J. Biol. Chem. 2014, 289, 22482-22489. [CrossRef]

117. McCann, J.C.; Ames, B.N. Is docosahexaenoic acid, an n-3 long-chain polyunsaturated fatty acid, required for development of normal brain function? An overview of evidence from cognitive and behavioral tests in humans and animals. Am. J. Clin. Nutr. 2005, 82, 281-295. [CrossRef]

118. Patel, J.V.; Tracey, I.; Hughes, E.A.; Lip, G.Y. Omega-3 polyunsaturated acids and cardiovascular disease: Notable ethnic differences or unfulfilled promise? J. Thromb. Haemost. 2010, 8, 2095-2104. [CrossRef]

119. Gu, Y.; Vorburger, R.S.; Gazes, Y.; Habeck, C.G.; Stern, Y.; Luchsinger, J.A.; Manly, J.J.; Schupf, N.; Mayeux, R.; Brickman, A.M. White matter integrity as a mediator in the relationship between dietary nutrients and cognition in the elderly. Ann. Neurol. 2016, 79, 1014-1025. [CrossRef]

120. Pottala, J.V.; Yaffe, K.; Robinson, J.G.; Espeland, M.A.; Wallace, R.; Harris, W.S. Higher RBC EPA + DHA corresponds with larger total brain and hippocampal volumes: WHIMS-MRI Study. Neurology 2014, 82, 435-442. [CrossRef]

121. Titova, O.E.; Sjögren, P.; Brooks, S.; Kullberg, J.; Ax, E.; Kilander, L.; Riserus, U.; Cederholm, T.; Larsson, E.-M.; Johansson, L.; et al Dietary intake of eicosapentaenoic and docosahexaenoic acids is linked to gray matter volume and cognitive function in elderly. AGE 2012, 35, 1495-1505. [CrossRef]

122. Samieri, C.; Maillard, P.; Crivello, F.; Proust-Lima, C.; Peuchant, E.; Helmer, C.; Amieva, H.; Allard, M.; Dartigues, J.-F.; Cunnane, S.C.; et al. Plasma long-chain omega-3 fatty acids and atrophy of the medial temporal lobe. Neurology 2012, 79, 642-650. [CrossRef]

123. Calder, P.C. Fatty acids and inflammation: The cutting edge between food and pharma. Eur. J. Pharmacol. 2011, 668 (Suppl. S1), S50-S58. [CrossRef]

124. Simopoulos, A.P. Evolutionary aspects of diet, the omega-6/omega-3 ratio and genetic variation: Nutritional implications for chronic diseases. Biomed. Pharmacother. 2006, 60, 502-507. [CrossRef] [PubMed]

125. Calder, P.C.; Albers, R.; Antoine, J.-M.; Blum, S.; Bourdet-Sicard, R.; Ferns, G.A.; Folkerts, G.; Friedmann, P.S.; Frost, G.S.; Guarner, F.; et al. Inflammatory Disease Processes and Interactions with Nutrition. Br. J. Nutr. 2009, 101, 1-45. [CrossRef] [PubMed]

126. Ben Gedalya, T.; Loeb, V.; Israeli, E.; Altschuler, Y.; Selkoe, D.J.; Sharon, R. $\alpha$-Synuclein and Polyunsaturated Fatty Acids Promote Clathrin-Mediated Endocytosis and Synaptic Vesicle Recycling. Traffic 2009, 10, 218-234. [CrossRef] [PubMed]

127. Assayag, K.; Yakunin, E.; Loeb, V.; Selkoe, D.J.; Sharon, R. Polyunsaturated Fatty Acids Induce $\alpha$-Synuclein-Related Pathogenic Changes in Neuronal Cells. Am. J. Pathol. 2007, 171, 2000-2011. [CrossRef]

128. De Franceschi, G.; Frare, E.; Pivato, M.; Relini, A.; Penco, A.; Greggio, E.; Bubacco, L.; Fontana, A.; de Laureto, P.P. Structural and Morphological Characterization of Aggregated Species of $\alpha$-Synuclein Induced by Docosahexaenoic Acid. J. Biol. Chem. 2011, 286, 22262-22274. [CrossRef]

129. Perrin, R.J.; Woods, W.S.; Clayton, D.F.; George, J.M. Exposure to Long Chain Polyunsaturated Fatty Acids Triggers Rapid Multimerization of Synucleins. J. Biol. Chem. 2001, 276, 41958-41962. [CrossRef]

130. Qin, Z.; Hu, D.; Han, S.; Reaney, S.H.; di Monte, D.; Fink, A.L. Effect of 4-Hydroxy-2-nonenal Modification on $\alpha$-Synuclein Aggregation. J. Biol. Chem. 2007, 282, 5862-5870. [CrossRef]

131. Puspita, L.; Chung, S.Y.; Shim, J.-W. Oxidative stress and cellular pathologies in Parkinson's disease. Mol. Brain 2017, 10, 1-12. [CrossRef]

132. Shamoto-Nagai, M.; Hisaka, S.; Naoi, M.; Maruyama, W. Modification of $\alpha$-synuclein by lipid peroxidation products derived from polyunsaturated fatty acids promotes toxic oligomerization: Its relevance to Parkinson disease. J. Clin. Biochem. Nutr. 2018, 62, 207-212. [CrossRef]

133. Galvagnion, C. The Role of Lipids Interacting with $\alpha$-Synuclein in the Pathogenesis of Parkinson's Disease. J. Park. Dis. 2017, 7 , 433-450. [CrossRef] 
134. De Franceschi, G.; Fecchio, C.; Sharon, R.; Schapira, A.H.V.; Proukakis, C.; Bellotti, V.; de Laureto, P.P. $\alpha$-Synuclein structural features inhibit harmful polyunsaturated fatty acid oxidation, suggesting roles in neuroprotection. J. Biol. Chem. 2017, 292, 6927-6937. [CrossRef]

135. Sharon, R.; Bar-Joseph, I.; Mirick, G.E.; Serhan, C.N.; Selkoe, D.J. Altered Fatty Acid Composition of Dopaminergic Neurons Expressing $\alpha$-Synuclein and Human Brains with $\alpha$-Synucleinopathies. J. Biol. Chem. 2003, 278, 49874-49881. [CrossRef] [PubMed]

136. Broersen, K.; Brink, D.V.D.; Fraser, G.; Goedert, M.; Davletov, B. $\alpha$-Synuclein Adopts an $\alpha$-Helical Conformation in the Presence of Polyunsaturated Fatty Acids to Hinder Micelle Formation. Biochemistry 2006, 45, 15610-15616. [CrossRef] [PubMed]

137. De Franceschi, G.; Frare, E.; Bubacco, L.; Mammi, S.; Fontana, A.; de Laureto, P.P. Molecular Insights into the Interaction between $\alpha$-Synuclein and Docosahexaenoic Acid. J. Mol. Biol. 2009, 394, 94-107. [CrossRef] [PubMed]

138. Ruipérez, V.; Darios, F.; Davletov, B. Alpha-synuclein, lipids and Parkinson's disease. Prog. Lipid Res. 2010, 49, 420-428. [CrossRef]

139. Yakunin, E.; Loeb, V.; Kisos, H.; Biala, Y.; Yehuda, S.; Yaari, Y.; Selkoe, D.J.; Sharon, R. $\alpha$-Synuclein Neuropathology is Controlled by Nuclear Hormone Receptors and Enhanced by Docosahexaenoic Acid in A Mouse Model for Parkinson's Disease. Brain Pathol. 2011, 22, 280-294. [CrossRef] [PubMed]

140. Fabelo, N.; Martín, V.; Santpere, G.; Marín, R.; Torrent, L.; Ferrer, I.; Díaz, M. Severe Alterations in Lipid Composition of Frontal Cortex Lipid Rafts from Parkinson's Disease and Incidental Parkinson's Disease. Mol. Med. 2011, 17, 1107-1118. [CrossRef]

141. Meng, Q.; Luchtman, D.W.; el Bahh, B.; Zidichouski, J.A.; Yang, J.; Song, C. Ethyl-eicosapentaenoate modulates changes in neurochemistry and brain lipids induced by parkinsonian neurotoxin 1-methyl-4-phenylpyridinium in mouse brain slices. Eur. J. Pharmacol. 2010, 649, 127-134. [CrossRef] [PubMed]

142. Chalimoniuk, M.; Stolecka-Warzecha, A.; Zieminska, E.; Stępień, A.; Langfort, J.; Strosznajder, J. Involvement of multiple protein kinases in cPLA2phosphorylation, arachidonic acid release, and cell death inin vivoandin vitromodels of 1-methyl-4phenylpyridinium-induced parkinsonism-The possible key role of PKG. J. Neurochem. 2009, 110, 307-317. [CrossRef]

143. Fecchio, C.; de Franceschi, G.; Relini, A.; Greggio, E.; Serra, M.D.; Bubacco, L.; de Laureto, P.P. $\alpha$-Synuclein Oligomers Induced by Docosahexaenoic Acid Affect Membrane Integrity. PLoS ONE 2013, 8, e82732. [CrossRef] [PubMed]

144. Riedel, M.; Goldbaum, O.; Wille, M.; Richter-Landsberg, C. Membrane Lipid Modification by Docosahexaenoic Acid (DHA) Promotes the Formation of $\alpha$-Synuclein Inclusion Bodies Immunopositive for SUMO-1 in Oligodendroglial Cells After Oxidative Stress. J. Mol. Neurosci. 2010, 43, 290-302. [CrossRef]

145. Ilan, Y. Compounds of the sphingomyelin-ceramide-glycosphingolipid pathways as secondary messenger molecules: New targets for novel therapies for fatty liver disease and insulin resistance. Am. J. Physiol. Gastrointest Liver Physiol. 2016, 310, G1102-G1117. [CrossRef] [PubMed]

146. Hannun, Y.A.; Obeid, L.M. Sphingolipids and their metabolism in physiology and disease. Nat. Rev. Mol. Cell Biol. 2017, 19, 175-191. [CrossRef]

147. Quinville, B.M.; Deschenes, N.M.; Ryckman, A.E.; Walia, J.S. A Comprehensive Review: Sphingolipid Metabolism and Implications of Disruption in Sphingolipid Homeostasis. Int. J. Mol. Sci. 2021, 22, 5793. [CrossRef]

148. Ventura, A.E.; Mestre, B.; Silva, L.C. Ceramide Domains in Health and Disease: A Biophysical Perspective. Adv. Exp. Med. Biol. 2019, 1159, 79-108. [CrossRef]

149. Sukocheva, O.A.; Furuya, H.; Ng, M.L.; Friedemann, M.; Menschikowski, M.; Tarasov, V.V.; Chubarev, V.N.; Klochkov, S.G.; Neganova, M.E.; Mangoni, A.A.; et al. Sphingosine kinase and sphingosine-1-phosphate receptor signaling pathway in inflammatory gastrointestinal disease and cancers: A novel therapeutic target. Pharmacol. Ther. 2020, 207, 107464. [CrossRef]

150. Zheng, X.; Li, W.; Ren, L.; Liu, J.; Pang, X.; Chen, X.; Kang, D.; Wang, J.; Du, G.; Zheng, X.; et al. The sphingosine kinase1/sphingosine-1-phosphate axis in cancer: Potential target for anticancer therapy. Pharmacol. Ther. 2018, 195, 85-99. [CrossRef]

151. Watson, L.; Tullus, K.; Marks, S.D.; Holt, R.C.L.; Pilkington, C.; Beresford, M.W. Increased Serum Concentration of Sphingosine-1phosphate in Juvenile-onset Systemic Lupus Erythematosus. J. Clin. Immunol. 2012, 32, 1019-1025. [CrossRef]

152. Mike, E.V.; Makinde, H.M.; Der, E.; Stock, A.; Gulinello, M.; Gadhvi, G.T.; Winter, D.R.; Cuda, C.M.; Putterman, C. Neuropsychiatric Systemic Lupus Erythematosus Is Dependent on Sphingosine-1-Phosphate Signaling. Front. Immunol. 2018, 9, 2189. [CrossRef]

153. Snider, A.J. Sphingosine kinase and sphingosine-1-phosphate: Regulators in autoimmune and inflammatory disease. Int. J. Clin. Rheumatol. 2013, 8, 453-463. [CrossRef]

154. Nagahashi, M.; Abe, M.; Sakimura, K.; Takabe, K.; Wakai, T. The role of sphingosine-1-phosphate in inflammation and cancer progression. Cancer Sci. 2018, 109, 3671-3678. [CrossRef]

155. Mihanfar, A.; Nejabati, H.R.; Fattahi, A.; Latifi, Z.; Pezeshkian, M.; Afrasiabi, A.; Safaie, N.; Jodati, A.R.; Nouri, M. The role of sphingosine 1 phosphate in coronary artery disease and ischemia reperfusion injury. J. Cell. Physiol. 2018, 234, $2083-2094$. [CrossRef]

156. Wang, E.; He, X.; Zeng, M. The Role of S1P and the Related Signaling Pathway in the Development of Tissue Fibrosis. Front. Pharmacol. 2019, 9, 1504. [CrossRef]

157. Ishay, Y.; Nachman, D.; Khoury, T.; Ilan, Y. The role of the sphingolipid pathway in liver fibrosis: An emerging new potential target for novel therapies. Am. J. Physiol. Physiol. 2020, 318, C1055-C1064. [CrossRef]

158. Taha, T.A.; Mullen, T.D.; Obeid, L.M. A house divided: Ceramide, sphingosine, and sphingosine-1-phosphate in programmed cell death. Biochim. Biophys. Acta (BBA)—Biomembr. 2006, 1758, 2027-2036. [CrossRef] [PubMed] 
159. Nagahashi, M.; Yamada, A.; Katsuta, E.; Aoyagi, T.; Huang, W.-C.; Terracina, K.P.; Hait, N.C.; Allegood, J.C.; Tsuchida, J.; Yuza, K.; et al. Targeting the SphK1/S1P/S1PR1 Axis That Links Obesity, Chronic Inflammation, and Breast Cancer Metastasis. Cancer Res. 2018, 78, 1713-1725. [CrossRef] [PubMed]

160. Wang, P.; Yuan, Y.; Lin, W.; Zhong, H.; Xu, K.; Qi, X. Roles of sphingosine-1-phosphate signaling in cancer. Cancer Cell Int. 2019, 19, 295. [CrossRef] [PubMed]

161. Gaspar, R.; Pallbo, J.; Weininger, U.; Linse, S.; Sparr, E. Ganglioside lipids accelerate $\alpha$-synuclein amyloid formation. Biochim. Biophys. Acta (BBA)—Proteins Proteom. 2018, 1866, 1062-1072. [CrossRef]

162. Clark, L.N.; Kisselev, S.; Park, N.; Ross, B.; Verbitsky, M.; Rios, E.; Alcalay, R.N.; Lee, J.H.; Louis, E.D. Mutations in the Parkinson's disease genes, Leucine Rich Repeat Kinase 2 (LRRK2) and Glucocerebrosidase (GBA), are not associated with essential tremor. Park. Relat. Disord. 2010, 16, 132-135. [CrossRef] [PubMed]

163. Pandey, M.K.; Burrow, T.A.; Rani, R.; Martin, L.J.; Witte, D.; Setchell, K.D.; McKay, M.A.; Magnusen, A.F.; Zhang, K.D.S.W.; Liou, B.; et al. Complement drives glucosylceramide accumulation and tissue inflammation in Gaucher disease. Nature 2017, 543, 108-112. [CrossRef] [PubMed]

164. Pandey, M.K.; Grabowski, G.A. Cytology of Gaucher disease. In Advances in Gaucher Disease: Basic and Clinical Perspectives; Future Medicine: London, UK, 2013; pp. 78-93.

165. Cullen, V.; Sardi, S.P.; Ng, J.; Xu, Y.H.; Sun, Y.; Tomlinson, J.J.; Kolodziej, P.; Kahn, I.; Saftig, P.; Woulfe, J.; et al. Acid $\beta$-glucosidase mutants linked to Gaucher disease, Parkinson disease, and Lewy body dementia alter $\alpha$-synuclein processing. Ann. Neurol. 2011, 69, 940-953. [CrossRef]

166. Pandey, M.K.; Grabowski, G.A. Immunological Cells and Functions in Gaucher Disease. Crit. Rev. Oncog. 2013, 18, 197-220. [CrossRef] [PubMed]

167. Pandey, M.K.; Rani, R.; Zhang, W.; Setchell, K.; Grabowski, G.A. Immunological cell type characterization and Th1-Th17 cytokine production in a mouse model of Gaucher disease. Mol. Genet. Metab. 2012, 106, 310-322. [CrossRef] [PubMed]

168. Abbott, S.K.; Li, H.; Muñoz, S.S.; Knoch, B.; Batterham, M.; Murphy, K.E.; Halliday, G.M.; Garner, B. Altered ceramide acyl chain length and ceramide synthase gene expression in Parkinson's disease. Mov. Disord. 2013, 29, 518-526. [CrossRef] [PubMed]

169. Du, T.-T.; Wang, L.; Duan, C.-L.; Lu, L.-L.; Zhang, J.-L.; Gao, G.; Qiu, X.-B.; Wang, X.-M.; Yang, H. GBA deficiency promotes SNCA / $\alpha$-synuclein accumulation through autophagic inhibition by inactivated PPP2A. Autophagy 2015, 11, 1803-1820. [CrossRef]

170. Atashrazm, F.; Hammond, D.; Perera, G.; Dobson-Stone, C.; Mueller, N.; Pickford, R.; Kim, W.S.; Kwok, J.B.; Lewis, S.; Halliday, G.M.; et al. Reduced glucocerebrosidase activity in monocytes from patients with Parkinson's disease. Sci. Rep. 2018, 8, 1-12. [CrossRef]

171. Hughes, L.P.; Pereira, M.M.; Hammond, D.A.; Kwok, J.B.; Halliday, G.M.; Lewis, S.J.; Dzamko, N. Glucocerebrosidase Activity is Reduced in Cryopreserved Parkinson's Disease Patient Monocytes and Inversely Correlates with Motor Severity. J. Park. Dis. 2021, 11, 1157-1165. [CrossRef]

172. Gündner, A.L.; Duran-Pacheco, G.; Zimmermann, S.; Ruf, I.; Moors, T.; Baumann, K.; Jagasia, R.; van de Berg, W.; Kremer, T. Path mediation analysis reveals GBA impacts Lewy body disease status by increasing $\alpha$-synuclein levels. Neurobiol. Dis. 2018, 121, 205-213. [CrossRef] [PubMed]

173. Taguchi, Y.V.; Liu, J.; Ruan, J.; Pacheco, J.; Zhang, X.; Abbasi, J.; Keutzer, J.; Mistry, P.K.; Chandra, S.S. Glucosylsphingosine Promotes $\alpha$-Synuclein Pathology in Mutant GBA-Associated Parkinson's Disease. J. Neurosci. 2017, 37, 9617-9631. [CrossRef] [PubMed]

174. Fonteh, A.N.; Chiang, A.J.; Arakaki, X.; Edminster, S.P.; Harrington, M.G. Accumulation of Cerebrospinal Fluid Glycerophospholipids and Sphingolipids in Cognitively Healthy Participants with Alzheimer's Biomarkers Precedes Lipolysis in the Dementia Stage. Front. Neurosci. 2020, 14. [CrossRef] [PubMed]

175. Guedes, L.C.; Chan, R.B.; Gomes, M.A.; Conceição, V.A.; Machado, R.B.; Soares, T.; Xu, Y.; Gaspar, P.; Carriço, J.A.; Alcalay, R.N.; et al. Serum lipid alterations in GBA-associated Parkinson's disease. Park. Relat. Disord. 2017, 44, 58-65. [CrossRef]

176. Ferrazza, R.; Cogo, S.; Melrose, H.; Bubacco, L.; Greggio, E.; Guella, G.; Civiero, L.; Plotegher, N. LRRK2 deficiency impacts ceramide metabolism in brain. Biochem. Biophys. Res. Commun. 2016, 478, 1141-1146. [CrossRef]

177. Torres-Odio, S.; Key, J.; Hoepken, H.-H.; Canet-Pons, J.; Valek, L.; Roller, B.; Walter, M.; Morales-Gordo, B.; Meierhofer, D.; Harter, P.N.; et al. Progression of pathology in PINK1-deficient mouse brain from splicing via ubiquitination, ER stress, and mitophagy changes to neuroinflammation. J. Neuroinflammation 2017, 14, 1-26. [CrossRef]

178. Cheng, D.; Jenner, A.M.; Shui, G.; Cheong, W.F.; Mitchell, T.W.; Nealon, J.R.; Kim, W.S.; McCann, H.; Wenk, M.R.; Halliday, G.M.; et al. Lipid Pathway Alterations in Parkinson's Disease Primary Visual Cortex. PLoS ONE 2011, 6, e17299. [CrossRef]

179. Seyfried, T.N.; Choi, H.; Chevalier, A.; Hogan, D.; Akgoc, Z.; Schneider, J.S. Sex-Related Abnormalities in Substantia Nigra Lipids in Parkinson's Disease. ASN Neuro 2018, 10, 1759091418781889. [CrossRef] [PubMed]

180. Kim, W.S.; Halliday, G.M. Changes in Sphingomyelin Level Affect Alpha-Synuclein and ABCA5 Expression. J. Park. Dis. 2012, 2, 41-46. [CrossRef]

181. Hannun, Y.A.; Luberto, C. Ceramide in the eukaryotic stress response. Trends Cell Biol. 2000, 10, 73-80. [CrossRef]

182. Lucki, N.C.; Sewer, M.B. Nuclear Sphingolipid Metabolism. Annu. Rev. Physiol. 2012, 74, 131-151. [CrossRef]

183. Ledeen, R.W.; Yu, R.K. [10] Gangliosides: Structure, isolation, and analysis. Methods Enzymol. 1982, 83, 139-191. [CrossRef] 
184. Ariga, T. The Pathogenic Role of Ganglioside Metabolism in Alzheimer's Disease-Cholinergic Neuron-Specific Gangliosides and Neurogenesis. Mol Neurobiol. 2017, 54, 623-638. [CrossRef] [PubMed]

185. Yu, R.K.; Nakatani, Y.; Yanagisawa, M. The role of glycosphingolipid metabolism in the developing brain. J. Lipid Res. 2009, 50, S440-S445. [CrossRef]

186. Schnaar, R.L. Glycolipid-mediated cell-cell recognition in inflammation and nerve regeneration. Arch. Biochem. Biophys. 2004, 426, 163-172. [CrossRef] [PubMed]

187. Van Echten-Deckert, G.; Guravi, G.V.E.-D.A.M. Golgi Localization of Glycosyltransferases Involved in Ganglioside Biosynthesis. Curr. Drug Targets 2008, 9, 282-291. [CrossRef]

188. Yamaji, T.; Hanada, K. Sphingolipid Metabolism and Interorganellar Transport: Localization of Sphingolipid Enzymes and Lipid Transfer Proteins. Traffic 2014, 16, 101-122. [CrossRef]

189. Möbius, W.; Herzog, V.; Sandhoff, K.; Schwarzmann, G. Intracellular Distribution of a Biotin-labeled Ganglioside, GM1, by Immunoelectron Microscopy after Endocytosis in Fibroblasts. J. Histochem. Cytochem. 1999, 47, 1005-1014. [CrossRef] [PubMed]

190. Chinnapen, D.J.-F.; Hsieh, W.-T.; Welscher, Y.M.T.; Saslowsky, D.E.; Kaoutzani, L.; Brandsma, E.; D'Auria, L.; Park, H.; Wagner, J.S.; Drake, K.R.; et al. Lipid Sorting by Ceramide Structure from Plasma Membrane to ER for the Cholera Toxin Receptor Ganglioside GM1. Dev. Cell 2012, 23, 573-586. [CrossRef]

191. Sano, R.; Annunziata, I.; Patterson, A.; Moshiach, S.; Gomero, E.; Opferman, J.; Forte, M.; D’Azzo, A. GM1-Ganglioside Accumulation at the Mitochondria-Associated ER Membranes Links ER Stress to Ca2+-Dependent Mitochondrial Apoptosis. Mol. Cell 2009, 36, 500-511. [CrossRef] [PubMed]

192. Sorice, M.; Garofalo, T.; Misasi, R.; Manganelli, V.; Vona, R.; Malorni, W. Ganglioside GD3 as a Raft Component in Cell Death Regulation. Anti-Cancer Agents Med. Chem. 2012, 12, 376-382. [CrossRef]

193. Xie, X.; Wu, G.; Lu, Z.-H.; Ledeen, R.W. Potentiation of a sodium-calcium exchanger in the nuclear envelope by nuclear GM1 ganglioside. J. Neurochem. 2002, 81, 1185-1195. [CrossRef] [PubMed]

194. Tsai, Y.-T.; Itokazu, Y.; Yu, R.K. GM1 Ganglioside is Involved in Epigenetic Activation Loci of Neuronal Cells. Neurochem. Res. 2015, 41, 107-115. [CrossRef] [PubMed]

195. Simpson, M.A.; Cross, H.; Proukakis, C.; Priestman, D.A.; Neville, D.C.A.; Reinkensmeier, G.; Wang, H.; Wiznitzer, M.; Gurtz, K.; Verganelaki, A.; et al. Infantile-onset symptomatic epilepsy syndrome caused by a homozygous loss-of-function mutation of GM3 synthase. Nat. Genet. 2004, 36, 1225-1229. [CrossRef] [PubMed]

196. Boukhris, A.; Schüle-Freyer, R.; Loureiro, J.L.; Lourenço, C.M.; Mundwiller, E.; Gonzalez, M.A.; Charles, P.; Gauthier, J.; Rekik, I.; Lebrigio, R.F.A.; et al. Alteration of Ganglioside Biosynthesis Responsible for Complex Hereditary Spastic Paraplegia. Am. J. Hum. Genet. 2013, 93, 118-123. [CrossRef] [PubMed]

197. Fragaki, K.; Ait-El-Mkadem, S.; Chaussenot, A.; Gire, C.; Mengual, R.; Bonesso, L.; Bénéteau, M.; Ricci, J.E.; Desquiret-Dumas, V.; Procaccio, V.; et al. Refractory epilepsy and mitochondrial dysfunction due to GM3 synthase deficiency. Eur. J. Hum. Genet. 2012, 21, 528-534. [CrossRef]

198. Harlalka, G.V.; Lehman, A.; Chioza, B.; Baple, E.L.; Maroofian, R.; Cross, H.; Sreekantan-Nair, A.; Priestman, D.A.; Al-Turki, S.; McEntagart, M.E.; et al. Mutations in B4GALNT1 (GM2 synthase) underlie a new disorder of ganglioside biosynthesis. Brain 2013, 136, 3618-3624. [CrossRef]

199. Boccuto, L.; Aoki, K.; Flanagan-Steet, H.; Chen, C.-F.; Fan, X.; Bartel, F.; Petukh, M.; Pittman, A.; Saul, R.A.; Chaubey, A.; et al. A mutation in a ganglioside biosynthetic enzyme, ST3GAL5, results in salt \& pepper syndrome, a neurocutaneous disorder with altered glycolipid and glycoprotein glycosylation. Hum. Mol. Genet. 2013, 23, 418-433. [CrossRef]

200. Wakil, S.M.; Monies, D.M.; Ramzan, K.; Hagos, S.; Bastaki, L.; Meyer, B.; Bohlega, S. NovelB4GALNT1mutations in a complicated form of hereditary spastic paraplegia. Clin. Genet. 2013, 86, 500-501. [CrossRef]

201. Allende, M.L.; Proia, R.L. Simplifying complexity: Genetically resculpting glycosphingolipid synthesis pathways in mice to reveal function. Glycoconj. J. 2014, 31, 613-622. [CrossRef]

202. Segler-Stahl, K.; Webster, J.C.; Brunngraber, E.G. Changes in the Concentration and Composition of Human Brain Gangliosides with Aging. Gerontology 1983, 29, 161-168. [CrossRef]

203. Palestini, P.; Masserini, M.; Sonnino, S.; Giuliani, A.; Tettamanti, G. Changes in the Ceramide Composition of Rat Forebrain Gangliosides with Age. J. Neurochem. 1990, 54, 230-235. [CrossRef] [PubMed]

204. Kracun, I.; Rosner, H.; Drnovsek, V.; Vukelic, Z.; Cosovic, C.; Trbojevic-Cepe, M.; Kubat, M. Gangliosides in the human brain development and aging. Neurochem. Int. 1992, 20, 421-431. [CrossRef]

205. Mo, L.; Ren, Q.; Duchemin, A.-M.; Neff, N.H.; Hadjiconstantinou, M. GM1 and ERK signaling in the aged brain. Brain Res. 2005, 1054, 125-134. [CrossRef]

206. Blennow, K.; Davidsson, P.; Wallin, A.; Fredman, P.; Gottfries, C.-G.; Karlsson, I.; Månsson, J.-E.; Svennerholm, L. Gangliosides in Cerebrospinal Fluid in "Probable Alzheimer's Disease". Arch. Neurol. 1991, 48, 1032-1035. [CrossRef]

207. Blennow, K.; Davidsson, P.; Wallin, A.; Frcdman, P.; Gottfries, C.G.; Mansson, J.; Svennerholm, L. Differences in cerebrospinal fluid gangliosides between "probable Alzheimer's disease" and normal aging. Aging Clin. Exp. Res. 1992, 4, 301-306. [CrossRef]

208. Desplats, P.; Denny, C.A.; Kass, K.E.; Gilmartin, T.; Head, S.R.; Sutcliffe, J.G.; Seyfried, T.; Thomas, E.A. Glycolipid and ganglioside metabolism imbalances in Huntington's disease. Neurobiol. Dis. 2007, 27, 265-277. [CrossRef] [PubMed]

209. Maglione, V.; Marchi, P.; di Pardo, A.; Lingrell, S.; Horkey, M.; Tidmarsh, E.; Sipione, S. Impaired Ganglioside Metabolism in Huntington's Disease and Neuroprotective Role of GM1. J. Neurosci. 2010, 30, 4072-4080. [CrossRef] 
210. Wu, G.; Lu, Z.-H.; Kulkarni, N.; Ledeen, R.W. Deficiency of ganglioside GM1 correlates with Parkinson's disease in mice and humans. J. Neurosci. Res. 2012, 90, 1997-2008. [CrossRef]

211. Di Pasquale, E.; Fantini, J.; Chahinian, H.; Maresca, M.; Taïeb, N.; Yahi, N. Altered Ion Channel Formation by the Parkinson'sDisease-Linked E46K Mutant of $\alpha$-Synuclein Is Corrected by GM3 but Not by GM1 Gangliosides. J. Mol. Biol. 2010, 397, 202-218. [CrossRef] [PubMed]

212. Grey, M.; Dunning, C.J.; Gaspar, R.; Grey, C.; Brundin, P.; Sparr, E.; Linse, S. Acceleration of $\alpha$-Synuclein Aggregation by Exosomes. J. Biol. Chem. 2015, 290, 2969-2982. [CrossRef]

213. Schneider, J.S. Altered expression of genes involved in ganglioside biosynthesis in substantia nigra neurons in Parkinson's disease. PLoS ONE 2018, 13, e0199189. [CrossRef] [PubMed]

214. Lobasso, S.; Tanzarella, P.; Vergara, D.; Maffia, M.; Cocco, T.; Corcelli, A. Lipid profiling of parkin -mutant human skin fibroblasts. J. Cell. Physiol. 2017, 232, 3540-3551. [CrossRef]

215. Yanagisawa, K.; Odaka, A.; Suzuki, N.; Ihara, Y. GM1 ganglioside-bound amyloid $\beta$-protein (A $\beta$ ): A possible form of preamyloid in Alzheimer's disease. Nat. Med. 1995, 1, 1062-1066. [CrossRef]

216. Hoshino, T.; Mahmood, I.; Mori, K.; Matsuzaki, K. Binding and Aggregation Mechanism of Amyloid $\beta$-Peptides onto the GM1 Ganglioside-Containing Lipid Membrane. J. Phys. Chem. B 2013, 117, 8085-8094. [CrossRef]

217. Chan, R.B.; Perotte, A.; Zhou, B.; Liong, C.; Shorr, E.J.; Marder, K.S.; Kang, U.J.; Waters, C.H.; Levy, O.A.; Xu, Y.; et al. Elevated GM3 plasma concentration in idiopathic Parkinson's disease: A lipidomic analysis. PLoS ONE 2017, 12, e0172348. [CrossRef]

218. Suzuki, K.; Iseki, E.; Togo, T.; Yamaguchi, A.; Katsuse, O.; Katsuyama, K.; Kanzaki, S.; Shiozaki, K.; Kawanishi, C.; Yamashita, S.; et al. Neuronal and glial accumulation of $\alpha$ - and $\beta$-synucleins in human lipidoses. Acta Neuropathol. 2007, 114, 481-489. [CrossRef] [PubMed]

219. Schneider, J.S.; Distefano, L. Response of the damaged dopamine system to gm1 and semisynthetic gangliosides: Effects of dose and extent of lesion. Neuropharmacology 1995, 34, 489-493. [CrossRef]

220. Park, J.-Y.; Kim, K.S.; Lee, S.-B.; Ryu, J.-S.; Chung, K.C.; Choo, Y.-K.; Jou, I.; Kim, J.; Park, S.M. On the mechanism of internalization of $\alpha$-synuclein into microglia: Roles of ganglioside GM1 and lipid raft. J. Neurochem. 2009, 110, 400-411. [CrossRef]

221. Reddan, J.M.; White, D.J.; Macpherson, H.; Scholey, A.; Pipingas, A. Glycerophospholipid Supplementation as a Potential Intervention for Supporting Cerebral Structure in Older Adults. Front. Aging Neurosci. 2018, 10, 49. [CrossRef]

222. Glomset, J.A. Role of docosahexaenoic acid in neuronal plasma membranes. Sci STKE. 2006. [CrossRef]

223. Farooqui, A.A.; Horrocks, L.A. Excitotoxicity and Neurological Disorders: Involvement of Membrane Phospholipids. In International Review of Neurobiology; Bradley, R.J., Harris, R.A., Eds.; Academic Press: Cambridge, MA, USA, 1994 ; pp. $267-323$.

224. Farooqui, A.A.; Horrocks, L.A. Plasmalogen-selective phospholipase A2 and its involvement in Alzheimer's disease. Biochem. Soc. Trans. 1998, 26, 243-245. [CrossRef] [PubMed]

225. Gattaz, W.F.; Maras, A.; Cairns, N.J.; Levy, R.; Förstl, H. Decreased phospholipase A2 activity in Alzheimer brains. Biol. Psychiatry 1995, 37, 13-17. [CrossRef]

226. Shvadchak, V.; Lockhart, L.J.F.; Yushchenko, D.A.; Jovin, T.M. Specificity and Kinetics of $\alpha$-Synuclein Binding to Model Membranes Determined with Fluorescent Excited State Intramolecular Proton Transfer (ESIPT) Probe. J. Biol. Chem. 2011, $286,13023-13032$. [CrossRef]

227. Davidson, W.S.; Jonas, A.; Clayton, D.F.; George, J.M. Stabilization of $\alpha$-Synuclein Secondary Structure upon Binding to Synthetic Membranes. J. Biol. Chem. 1998, 273, 9443-9449. [CrossRef] [PubMed]

228. Sztacho, M.; Šalovská, B.; Červenka, J.; Balaban, C.; Hoboth, P.; Hozák, P. Limited Proteolysis-Coupled Mass Spectrometry Identifies Phosphatidylinositol 4,5-Bisphosphate Effectors in Human Nuclear Proteome. Cells 2021, 10, 68. [CrossRef]

229. Frere, S.G.; Chang-Ileto, B.; di Paolo, G. Role of Phosphoinositides at the Neuronal Synapse. Subcell. Biochem. 2012, 59, 131-175. [CrossRef]

230. Alza, N.P.; Iglesias González, P.A.; Conde, M.A.; Uranga, R.M.; Salvador, G.A. Lipids at the Crossroad of $\alpha$-Synuclein Function and Dysfunction: Biological and Pathological Implications. Front. Cell. Neurosci. 2019, 13, 175. [CrossRef] [PubMed]

231. Liu, Y.; Su, Y.; Wang, X. Phosphatidic Acid-Mediated Signaling. Adv. Exp. Med. Biol. 2013, 991, 159-176. [CrossRef]

232. Perrin, R.J.; Woods, W.S.; Clayton, D.F.; George, J.M. Interaction of human alpha-Synuclein and Parkinson's disease variants with phospholipids. Structural analysis using site-directed mutagenesis. J. Biol. Chem. 2000, 275, 34393-34398. [CrossRef]

233. Zhao, H.; Wang, C.; Zhao, N.; Li, W.; Yang, Z.; Liu, X.; Le, W.; Zhang, X. Potential biomarkers of Parkinson's disease revealed by plasma metabolic profiling. J. Chromatogr. B Analyt. Technol. Biomed. Life Sci. 2018, 1081-1082, 101-108. [CrossRef]

234. Jiang, Z.; Flynn, J.D.; Teague, W.E., Jr.; Gawrisch, K.; Lee, J.C. Stimulation of $\alpha$-synuclein amyloid formation by phosphatidylglycerol micellar tubules. Biochim. Biophys. Acta (BBA)—Biomembr. 2018, 1860, 1840-1847. [CrossRef]

235. Xicoy, H.; Wieringa, B.; Martens, G.J.M. The Role of Lipids in Parkinson's Disease. Cells 2019, 8, 27. [CrossRef]

236. Zhang, J.; Zhang, X.; Wang, L.; Yang, C. High Performance Liquid Chromatography-Mass Spectrometry (LC-MS) Based Quantitative Lipidomics Study of Ganglioside-NANA-3 Plasma to Establish Its Association with Parkinson's Disease Patients. Med Sci. Monit. 2017, 23, 5345-5353. [CrossRef] [PubMed]

237. Prior, I.A.; Hancock, J.F. Compartmentalization of Ras proteins. J. Cell Sci. 2001, 114, 1603-1608. [CrossRef]

238. Simons, M.; Keller, P.; Dichgans, J.; Schulz, J.B. Cholesterol and Alzheimer's disease: Is there a link? Neurology 2001, 57, 1089-1093. [CrossRef] 
239. Mauch, D.H.; Nägler, K.; Schumacher, S.; Göritz, C.; Müller, E.-C.; Otto, A.; Pfrieger, F.W. CNS Synaptogenesis Promoted by Glia-Derived Cholesterol. Science 2001, 294, 1354-1357. [CrossRef] [PubMed]

240. Goritz, C.; Mauch, D.H.; Pfrieger, F.W. Multiple mechanisms mediate cholesterol-induced synaptogenesis in a CNS neuron. Mol. Cell. Neurosci. 2005, 29, 190-201. [CrossRef]

241. Russell, D.W.; Setchell, K.D.R. Bile acid biosynthesis. Biochemistry 1992, 31, 4737-4749. [CrossRef] [PubMed]

242. Lewis, G.F. Determinants of plasma HDL concentrations and reverse cholesterol transport. Curr. Opin. Cardiol. 2006, 21, 345-352. [CrossRef]

243. Hampton, R.; Dimster-Denk, D.; Rine, J. The biology of HMG-CoA reductase: The pros of contra-regulation. Trends Biochem. Sci. 1996, 21, 140-145. [CrossRef]

244. Elshourbagy, N.A.; Meyers, H.V.; Abdel-Meguid, S.S. Cholesterol: The Good, the Bad, and the Ugly-Therapeutic Targets for the Treatment of Dyslipidemia. Med Princ. Pr. 2013, 23, 99-111. [CrossRef]

245. Rosenson, R.S.; Song, W.-L. Egg yolk, source of bad cholesterol and good lipids? Am. J. Clin. Nutr. 2019, 110, 548-549. [CrossRef] [PubMed]

246. Porter, F.D.; Herman, G.E. Malformation syndromes caused by disorders of cholesterol synthesis. J. Lipid Res. 2011, 52, 6-34. [CrossRef] [PubMed]

247. Khosla, P.; Hayes, K.C. Dietary palmitic acid raises plasma LDL cholesterol relative to oleic acid only at a high intake of cholesterol. Biochim. Biophys. Acta (BBA)—Lipids Lipid Metab. 1993, 1210, 13-22. [CrossRef]

248. Pollin, T.I.; Quartuccio, M. What We Know About Diet, Genes, and Dyslipidemia: Is There Potential for Translation? Curr. Nutr. Rep. 2013, 2, 236-242. [CrossRef]

249. Jira, P. Cholesterol metabolism deficiency. Handb. Clin. Neurol. 2013, 113, 1845-1850. [CrossRef]

250. Kluck, G.E.G.; Yoo, J.-A.; Sakarya, E.H.; Trigatti, B.L. Good Cholesterol Gone Bad? HDL and COVID-19. Int. J. Mol. Sci. 2021, 22, 10182. [CrossRef]

251. Feig, J.E.; Hewing, B.; Smith, J.D.; Hazen, S.L.; Fisher, E.A. High-Density Lipoprotein and Atherosclerosis Regression. Circ. Res. 2014, 114, 205-213. [CrossRef]

252. Kratzer, A.; Giral, H.; Landmesser, U. High-density lipoproteins as modulators of endothelial cell functions: Alterations in patients with coronary artery disease. Cardiovasc. Res. 2014, 103, 350-361. [CrossRef]

253. Moghadasian, M.H.; Salen, G.; Frohlich, J.J.; Scudamore, C.H. Cerebrotendinous Xanthomatosis: A Rare Disease with Diverse Manifestations. Arch. Neurol. 2002, 59, 527-529. [CrossRef]

254. Puntoni, M.; Sbrana, F.; Bigazzi, F.; Sampietro, T. Tangier Disease: Epidemiology, pathophysiology, and management. Am. J. Cardiovasc. Drugs 2012, 12. [CrossRef]

255. Lester, D. Serum cholesterol levels and suicide: A meta-analysis. Suicide Life-Threatening Behav. 2002, 32, 333-346. [CrossRef] [PubMed]

256. Fawcett, J.; Busch, K.A.; Jacobs, D.; Kravitz, H.M.; Fogg, L. Suicide: A four-pathway clinical-biochemical model. Ann. New York Acad. Sci. 1997, 836, 288-301. [CrossRef] [PubMed]

257. Martínez-Carpio, P.A.; Barba, J.; Campillo, A.B.-D. Relation between cholesterol levels and neuropsychiatric disorders. Rev. Neurol. 2009, 48, 261-264. (In Spanish) [PubMed]

258. Valenza, M.; Rigamonti, D.; Goffredo, D.; Zuccato, C.; Fenu, S.; Jamot, L.; Strand, A.; Tarditi, A.; Woodman, B.; Racchi, M.; et al. Dysfunction of the Cholesterol Biosynthetic Pathway in Huntington's Disease. J. Neurosci. 2005, 25, 9932-9939. [CrossRef]

259. Varghese, M.J. Familial hypercholesterolemia: A review. Ann. Pediatr. Cardiol. 2014, 7, 107-117. [CrossRef]

260. Wang, X.; Dong, Y.; Qi, X.; Huang, C.; Hou, L. Cholesterol Levels and Risk of Hemorrhagic Stroke: A systematic review and meta-analysis. Stroke 2013, 44, 1833-1839. [CrossRef]

261. Ancelin, M.-L.; Carriere, I.; Boulenger, J.-P.; Malafosse, A.; Stewart, R.; Cristol, J.-P.; Ritchie, K.; Chaudieu, I.; Dupuy, A.M. Gender and Genotype Modulation of the Association Between Lipid Levels and Depressive Symptomatology in Community-Dwelling Elderly (The ESPRIT Study). Biol. Psychiatry 2010, 68, 125-132. [CrossRef]

262. Kim, K.-Y.; Stevens, M.V.; Akter, M.H.; Rusk, S.E.; Huang, R.J.; Cohen, A.; Noguchi, A.; Springer, D.; Bocharov, A.V.; Eggerman, T.L.; et al. Parkin is a lipid-responsive regulator of fat uptake in mice and mutant human cells. J. Clin. Investig. 2011, 121, 3701-3712. [CrossRef]

263. Eriksson, I.; Nath, S.; Bornefall, P.; Giraldo, A.M.V.; Öllinger, K. Impact of high cholesterol in a Parkinson's disease model: Prevention of lysosomal leakage versus stimulation of $\alpha$-synuclein aggregation. Eur. J. Cell Biol. 2017, 96, 99-109. [CrossRef] [PubMed]

264. Kamp, F.; Beyer, K. Binding of $\alpha$-Synuclein Affects the Lipid Packing in Bilayers of Small Vesicles. J. Biol. Chem. 2006, 281, 9251-9259. [CrossRef]

265. Bar-On, P.; Rockenstein, E.; Adame, A.; Ho, G.; Hashimoto, M.; Masliah, E. Effects of the cholesterol-lowering compound methyl- $\beta$-cyclodextrin in models of $\alpha$-synucleinopathy. J. Neurochem. 2006, 98, 1032-1045. [CrossRef] [PubMed]

266. Gregório, M.; Pinhel, M.A.S.; Sado, C.L.; Longo, G.S.; Oliveira, F.N.; Amorim, G.S.; Nakazone, M.A.; Florim, G.M.; Mazeti, C.M.; Martins, D.P.; et al. Impact of Genetic Variants of Apolipoprotein E on Lipid Profile in Patients with Parkinson's Disease. BioMed Res. Int. 2013, 2013, 1-7. [CrossRef]

267. Zhang, L.; Wang, X.; Wang, M.; Sterling, N.W.; Du, G.; Lewis, M.M.; Yao, T.; Mailman, R.B.; Li, R.; Huang, X. Circulating Cholesterol Levels May Link to the Factors Influencing Parkinson's Risk. Front. Neurol. 2017, 8. [CrossRef] [PubMed] 
268. Huang, X.; Alonso, A.; Guo, X.; Umbach, D.M.; Lichtenstein, M.L.; Ballantyne, C.M.; Mailman, R.; Mosley, T.H.; Chen, H. Statins, plasma cholesterol, and risk of Parkinson's disease: A prospective study. Mov. Disord. 2015, 30, 552-559. [CrossRef]

269. Ma, V.R.; Gurevich, T.; Giladi, N.; El-Ad, B.; Tsamir, J.; Hemo, B.; Peretz, C. Higher serum cholesterol and decreased Parkinson's disease risk: A statin-free cohort study. Mov. Disord. 2018, 33, 1298-1305. [CrossRef]

270. Gudala, K.; Bansal, D.; Muthyala, H. Role of Serum Cholesterol in Parkinson's Disease: A Meta-Analysis of Evidence. J. Park. Dis. 2013, 3, 363-370. [CrossRef]

271. Magalhaes, J.; Gegg, M.E.; Migdalska-Richards, A.; Doherty, M.K.; Whitfield, P.D.; Schapira, A.H. Autophagic lysosome reformation dysfunction in glucocerebrosidase deficient cells: Relevance to Parkinson disease. Hum. Mol. Genet. 2016, 25, 3432-3445. [CrossRef] [PubMed]

272. Guerreiro, P.; Coelho, J.; Sousa-Lima, I.; Macedo, M.P.; Lopes, L.V.; Outeiro, T.F.; Pais, T.F. Mutant A53T $\alpha$-Synuclein Improves Rotarod Performance Before Motor Deficits and Affects Metabolic Pathways. NeuroMolecular Med. 2016, 19, 113-121. [CrossRef]

273. Yamaguchi, S.; Yamane, T.; Takahashi-Niki, K.; Kato, I.; Niki, T.; Goldberg, M.S.; Shen, J.; Ishimoto, K.; Doi, T.; Iguchi-Ariga, S.M.M.; et al. Transcriptional Activation of Low-Density Lipoprotein Receptor Gene by DJ-1 and Effect of DJ-1 on Cholesterol Homeostasis. PLoS ONE 2012, 7, e38144. [CrossRef]

274. Shioda, N.; Yabuki, Y.; Kobayashi, Y.; Onozato, M.; Owada, Y.; Fukunaga, K. FABP3 Protein Promotes $\alpha$-Synuclein Oligomerization Associated with 1-Methyl-1,2,3,6-tetrahydropiridine-induced Neurotoxicity. J. Biol. Chem. 2014, 289, 18957-18965. [CrossRef] [PubMed]

275. Vos, M.; Geens, A.; Böhm, C.; Deaulmerie, L.; Swerts, J.; Rossi, M.; Craessaerts, K.; Leites, E.; Seibler, P.; Rakovic, A.; et al. Cardiolipin promotes electron transport between ubiquinone and complex I to rescue PINK1 deficiency. J. Cell Biol. 2017, 216, 695-708. [CrossRef]

276. Cha, S.-H.; Choi, Y.R.; Heo, C.-H.; Kang, S.-J.; Joe, E.-H.; Jou, I.; Kim, H.-M.; Park, S.M. Loss of parkin promotes lipid raftsdependent endocytosis through accumulating caveolin-1: Implications for Parkinson's disease. Mol. Neurodegener. 2015, 10, 63. [CrossRef]

277. Guo, X.; Song, W.; Chen, K.; Chen, X.; Zheng, Z.; Cao, B.; Huang, R.; Zhao, B.; Wu, Y.; Shang, H.-F. The serum lipid profile of Parkinson's disease patients: A study from China. Int. J. Neurosci. 2014, 125, 838-844. [CrossRef]

278. Ogburn, K.D.; Figueiredo-Pereira, M.E. Cytoskeleton/Endoplasmic Reticulum Collapse Induced by Prostaglandin J2 Parallels Centrosomal Deposition of Ubiquitinated Protein Aggregates. J. Biol. Chem. 2006, 281, 23274-23284. [CrossRef] [PubMed]

279. Abbott, S.K.; Jenner, A.M.; Spiro, A.S.; Batterham, M.; Halliday, G.M.; Garner, B. Fatty Acid Composition of the Anterior Cingulate Cortex Indicates a High Susceptibility to Lipid Peroxidation in Parkinson's Disease. J. Park. Dis. 2015, 5, 175-185. [CrossRef]

280. Lenz, K.M.; Nelson, L. Microglia and Beyond: Innate Immune Cells as Regulators of Brain Development and Behavioral Function. Front. Immunol. 2018, 9, 698. [CrossRef] [PubMed]

281. Kim, Y.S.; Joh, T.H. Microglia, major player in the brain inflammation: Their roles in the pathogenesis of Parkinson's disease. Exp. Mol. Med. 2006, 38, 333-347. [CrossRef]

282. Guerrini, V.; Gennaro, M.L. Foam Cells: One Size Doesn't Fit All. Trends Immunol. 2019, 40, 1163-1179. [CrossRef]

283. Thiam, A.R.; Farese, R.V.F., Jr.; Walther, T.C. The biophysics and cell biology of lipid droplets. Nat. Rev. Mol. Cell Biol. 2013, 14, 775-786. [CrossRef] [PubMed]

284. Huang, S.C.-C.; Everts, B.; Ivanova, Y.; O’Sullivan, D.; Nascimento, M.; Smith, A.M.; Beatty, W.; Love-Gregory, L.; Lam, W.Y.; O'Neill, C.M.; et al. Cell-intrinsic lysosomal lipolysis is essential for alternative activation of macrophages. Nat. Immunol. 2014, 15, 846-855. [CrossRef]

285. Li, A.C.; Glass, C.K. The macrophage foam cell as a target for therapeutic intervention. Nat. Med. 2002, 8, 1235-1242. [CrossRef]

286. Castoldi, A.; Monteiro, L.B.; Bakker, N.V.T.; Sanin, D.E.; Rana, N.; Corrado, M.; Cameron, A.M.; Hässler, F.; Matsushita, M.; Caputa, G.; et al. Triacylglycerol synthesis enhances macrophage inflammatory function. Nat. Commun. 2020, 11, 1-11. [CrossRef] [PubMed]

287. Pandey, M.K.; Grabowski, G.A.; Köhl, J. An unexpected player in Gaucher disease: The multiple roles of complement in disease development. Semin. Immunol. 2018, 37, 30-42. [CrossRef]

288. Van Eijk, M.; Aerts, J.M. The Unique Phenotype of Lipid-Laden Macrophages. Int. J. Mol. Sci. 2021, 22, 4039. [CrossRef] [PubMed]

289. Serfecz, J.C.; Saadin, A.; Santiago, C.P.; Zhang, Y.; Bentzen, S.M.; Vogel, S.N.; Feldman, R.A. C5a Activates a Pro-Inflammatory Gene Expression Profile in Human Gaucher iPSC-Derived Macrophages. Int. J. Mol. Sci. 2021, 22, 9912. [CrossRef]

290. Magnusen, A.F.; Rani, R.; McKay, M.A.; Hatton, S.L.; Nyamajenjere, T.C.; Magnusen, D.N.A.; Köhl, J.; Grabowski, G.A.; Pandey, M.K. C-X-C Motif Chemokine Ligand 9 and Its CXCR3 Receptor Are the Salt and Pepper for T Cells Trafficking in a Mouse Model of Gaucher Disease. Int. J. Mol. Sci. 2021, 22, 12712. [CrossRef] [PubMed]

291. Qin, X.-Y.; Zhang, S.-P.; Cao, C.; Loh, Y.P.; Cheng, Y. Aberrations in Peripheral Inflammatory Cytokine Levels in Parkinson Disease: A Systematic Review and Meta-analysis. JAMA Neurol. 2016, 73, 1316-1324. [CrossRef] [PubMed]

292. Lin, C.-H.; Chen, C.-C.; Chiang, H.-L.; Liou, J.-M.; Chang, C.-M.; Lu, T.-P.; Chuang, E.Y.; Tai, Y.-C.; Cheng, C.; Lin, H.-Y.; et al. Altered gut microbiota and inflammatory cytokine responses in patients with Parkinson's disease. J. Neuroinflammation 2019, 16, 1-9. [CrossRef]

293. Chao, Y.; Wong, S.C.; Tan, E.K. Evidence of Inflammatory System Involvement in Parkinson's Disease. BioMed Res. Int. 2014, 2014, 1-9. [CrossRef] 
294. Lawson, L.J.; Perry, V.H.; Dri, P.; Gordon, S. Heterogeneity in the distribution and morphology of microglia in the normal adult mouse brain. Neuroscience 1990, 39, 151-170. [CrossRef]

295. Ho, M.S. Microglia in Parkinson's Disease. Adv. Exp. Med. Biol. 2019, 1175, 335-353. [CrossRef]

296. Lecours, C.; Bordeleau, M.; Cantin, L.; Parent, M.; di Paolo, T.; Tremblay, M. Microglial Implication in Parkinson's Disease: Loss of Beneficial Physiological Roles or Gain of Inflammatory Functions? Front. Cell. Neurosci. 2018, 12, 282. [CrossRef] [PubMed]

297. Feingold, K.R.; Grunfeld, C. Role of Cytokines in Inducing Hyperlipidemia. Diabetes 1992, 41 (Suppl 2), 97-101. [CrossRef]

298. Tavares, F.L.; Seelaender, M.C.L. Hepatic denervation impairs the assembly and secretion of VLDL-TAG. Cell Biochem. Funct. 2008, 26, 557-565. [CrossRef] [PubMed]

299. Kawahara, K.; Hohjoh, H.; Inazumi, T.; Tsuchiya, S.; Sugimoto, Y. Prostaglandin E2-induced inflammation: Relevance of prostaglandin E receptors. Biochim. Biophys. Acta (BBA)—Mol. Cell Biol. Lipids 2014, 1851, 414-421. [CrossRef]

300. Geng, Y.; Fang, M.; Wang, J.; Yu, H.; Hu, Z.; Yew, D.T.; Chen, W. Triptolide Down-regulates COX-2 Expression and PGE2 Release by Suppressing the Activity of NF-kB and MAP kinases in Lipopolysaccharide-treated PC12 Cells. Phytotherapy Res. 2011, 26, 337-343. [CrossRef] [PubMed]

301. Zeng, K.-W.; Zhang, T.; Fu, H.; Liu, G.-X.; Wang, X.-M. Schisandrin B exerts anti-neuroinflammatory activity by inhibiting the Toll-like receptor 4-dependent MyD88/IKK/NF- kB signaling pathway in lipopolysaccharide-induced microglia. Eur. J. Pharmacol. 2012, 692, 29-37. [CrossRef]

302. Liu, J.; Zhou, Y.; Wang, Y.; Fong, H.; Murray, A.T.M.; Zhang, J. Identification of Proteins Involved in Microglial Endocytosis of

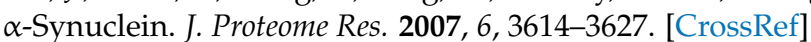

303. Dey, I.; Lejeune, M.; Chadee, K. Prostaglandin E2receptor distribution and function in the gastrointestinal tract. J. Cereb. Blood Flow Metab. 2006, 149, 611-623. [CrossRef]

304. Yu, S.-Y.; Zuo, L.-J.; Wang, F.; Chen, Z.-J.; Hu, Y.; Wang, Y.-J.; Wang, X.-M.; Zhang, W. Potential biomarkers relating pathological proteins, neuroinflammatory factors and free radicals in PD patients with cognitive impairment: A cross-sectional study. BMC Neurol. 2014, 14, 113. [CrossRef]

305. Ashley, A.K.; Hinds, A.I.; Hanneman, W.H.; Tjalkens, R.B.; Legare, M.E. DJ-1 mutation decreases astroglial release of inflammatory mediators. NeuroToxicology 2016, 52, 198-203. [CrossRef]

306. Ahmad, A.S.; Maruyama, T.; Narumiya, S.; Doré, S. PGE2 EP1 Receptor Deletion Attenuates 6-OHDA-Induced Parkinsonism in Mice: Old Switch, New Target. Neurotox. Res. 2013, 23, 260-266. [CrossRef]

307. Carrasco, E.; Werner, P.; Casper, D. Prostaglandin receptor EP2 protects dopaminergic neurons against 6-OHDA-mediated low oxidative stress. Neurosci. Lett. 2008, 441, 44-49. [CrossRef]

308. Pradhan, S.S.; Salinas, K.; Garduno, A.C.; Johansson, J.U.; Wang, Q.; Manning-Bog, A.; Andreasson, K.I. Anti-Inflammatory and Neuroprotective Effects of PGE2 EP4 Signaling in Models of Parkinson's Disease. J. Neuroimmune Pharmacol. 2016, 12, 292-304. [CrossRef] [PubMed]

309. Roeske-Nielsen, A.; Fredman, P.; Mansson, J.E.; Bendtzen, K.; Buschard, K. Beta-galactosylceramide increases and sulfatide decreases cytokine and chemokine production in whole blood cells. Immunol. Lett. 2004, 91, 205-211. [CrossRef] [PubMed]

310. Buschard, K.; Josefsen, K.; Horn, T.; Larsen, S.; Fredman, P. Sulphatide antigen in islets of Langerhans and in diabetic glomeruli, and anti-sulphatide antibodies in Type 1 diabetes mellitus. APMIS 1993, 101, 963-970. [CrossRef] [PubMed]

311. Fredman, P.; Månsson, J.-E.; Rynmark, B.-M.; Josefsen, K.; Ekblond, A.; Halldner, L.; Osterbye, T.; Horn, T.; Buschard, K. The glycosphingolipid sulfatide in the islets of Langerhans in rat pancreas is processed through recycling: Possible involvement in insulin trafficking. Glycobiology 2000, 10, 39-50. [CrossRef] [PubMed]

312. Bendtzen, K.; Mandrup-Poulsen, T.; Nerup, J.; Nielsen, J.H.; Dinarello, C.A.; Svenson, M. Cytotoxicity of Human p I 7 Interleukin-1 for Pancreatic Islets of Langerhans. Science 1986, 232, 1545-1547. [CrossRef]

313. Buschard, K.; Schloot, N.C.; Kaas, A.; Bock, T.; Horn, T.; Fredman, P.; Roep, B.O. Inhibition of insulin-specific autoreactive T-cells by sulphatide which is variably expressed in beta cells. Diabetologia 1999, 42, 1212-1218. [CrossRef]

314. Pan, H.; Zhang, G.; Nie, H.; Li, S.; He, S.; Yang, J. Sulfatide-activated type II NKT cells suppress immunogenic maturation of lung dendritic cells in murine models of asthma. Am. J. Physiol. Cell. Mol. Physiol. 2019, 317, L578-L590. [CrossRef] [PubMed]

315. Takeuchi, O.; Akira, S. RIG-I-like antiviral protein in flies. Nat. Immunol. 2008, 9, 1327-1328. [CrossRef]

316. Matzinger, P. Friendly and dangerous signals: Is the tissue in control? Nat. Immunol. 2007, 8, 11-13. [CrossRef]

317. Alisi, A.; Carsetti, R.; Nobili, V. Pathogen- or damage-associated molecular patterns during nonalcoholic fatty liver disease development. Hepatology 2011, 54, 1500-1502. [CrossRef] [PubMed]

318. Pisetsky, D.S.; Gauley, J.; Ullal, A.J. HMGB1 and Microparticles as Mediators of the Immune Response to Cell Death. Antioxidants Redox Signal. 2011, 15, 2209-2219. [CrossRef] [PubMed]

319. Ochiel, D.O.; Rossoll, R.M.; Schaefer, T.M.; Wira, C.R. Effect of oestradiol and pathogen-associated molecular patterns (PAMP) on class II-mediated antigen presentation and immunomodulatory molecule expression in the mouse female reproductive tract. Immunology 2011, 135, 51-62. [CrossRef]

320. Blum, J.S.; Wearsch, P.A.; Cresswell, P. Pathways of Antigen Processing. Annu. Rev. Immunol. 2013, 31, 443-473. [CrossRef] [PubMed]

321. Neefjes, J.; Jongsma, M.L.M.; Paul, P.; Bakke, O. Towards a systems understanding of MHC class I and MHC class II antigen presentation. Nat. Rev. Immunol. 2011, 11, 823-836. [CrossRef] 
322. Lu, G.-H.; Zhang, S.-Z.; Wang, B.-Y.; Ye, Y.-Y.; Qian, C.; Zhang, H.-B.; Mao, H.-X.; Yao, L.-P.; Sun, X. Stress increases MHC-I expression in dopaminergic neurons and induces autoimmune activation in Parkinson's disease. Neural Regen. Res. 2021, 16, 2521-2527. [CrossRef]

323. Sulzer, D.; Alcalay, R.N.; Garretti, F.; Cote, L.; Kanter, E.; Agin-Liebes, J.; Liong, C.; McMurtrey, C.; Hildebrand, W.H.; Mao, X.; et al $\mathrm{T}$ cells from patients with Parkinson's disease recognize $\alpha$-synuclein peptides. Nature 2017, 546, 656-661. [CrossRef] [PubMed]

324. Jimenez-Ferrer, I.; Bäckström, F.; Dueñas-Rey, A.; Jewett, M.; Boza-Serrano, A.; Luk, K.C.; Deierborg, T.; Swanberg, M. The MHC class II transactivator modulates seeded alpha-synuclein pathology and dopaminergic neurodegeneration in an in vivo rat model of Parkinson's disease. Brain Behav. Immun. 2021, 91, 369-382. [CrossRef] [PubMed]

325. Pamer, E.; Cresswell, P. Mechanisms of Mhc Class I-Restricted Antigen Processing. Annu. Rev. Immunol. 1998, 16, 323-358. [CrossRef] [PubMed]

326. Cresswell, P. Assembly, Transport, and Function of MHC Class II Molecules. Annu. Rev. Immunol. 1994, 12, 259-291. [CrossRef] [PubMed]

327. Yin, L.; Huseby, E.; Scott-Browne, J.; Rubtsova, K.; Pinilla, C.; Crawford, F.; Marrack, P.; Dai, S.; Kappler, J.W. A Single T Cell Receptor Bound to Major Histocompatibility Complex Class I and Class II Glycoproteins Reveals Switchable TCR Conformers. Immunity 2011, 35, 23-33. [CrossRef] [PubMed]

328. Bleicher, P.A.; Balk, S.P.; Hagen, S.J.; Blumberg, R.S.; Flotte, T.J.; Terhorst, C. Expression of Murine CD1 on Gastrointestinal Epithelium. Science 1990, 250, 679-682. [CrossRef]

329. Porcelli, S.A.; Modlin, R.L. THE CD1 SYSTEM: Antigen-Presenting Molecules for T Cell Recognition of Lipids and Glycolipids. Annu. Rev. Immunol. 1999, 17, 297-329. [CrossRef]

330. Vincent, M.S.; Xiong, X.; Grant, E.P.; Peng, W.; Brenner, M.B. CD1a-, b-, and c-Restricted TCRs Recognize Both Self and Foreign Antigens. J. Immunol. 2005, 175, 6344-6351. [CrossRef] [PubMed]

331. Grant, E.P.; Degano, M.; Rosat, J.-P.; Stenger, S.; Modlin, R.; Wilson, I.A.; Porcelli, S.A.; Brenner, M.B. Molecular Recognition of Lipid Antigens by T Cell Receptors. J. Exp. Med. 1999, 189, 195-205. [CrossRef]

332. Shamshiev, A.; Donda, A.; Carena, I.; Mori, L.; Kappos, L.; de Libero, G. Self glycolipids as T-cell auto-antigens. Eur. J. Immunol. 1999, 29, 1667-1675. [CrossRef]

333. Mattner, J.; DeBord, K.L.; Ismail, N.; Goff, R.D.; Cantu, C.; Zhou, D.; Saint-Mezard, P.; Wang, V.; Gao, Y.; Yin, N.; et al. Exogenous and endogenous glycolipid antigens activate NKT cells during microbial infections. Nature 2005, 434, 525-529. [CrossRef] [PubMed]

334. Cohen, N.R.; Garg, S.; Brenner, M.B. Antigen Presentation by CD1 Lipids, T Cells, and NKT Cells in Microbial Immunity. Adv. Immunol. 2009, 102, 1-94. [CrossRef]

335. Brigl, M.; Brenner, M.B. CD1: Antigen Presentation and T Cell Function (Review). Annu. Rev. Immunol. 2004, 22, 817-890. [CrossRef]

336. Albutti, A.; Longet, S.; McEntee, C.; Quinn, S.; Liddicoat, A.; Rîmniceanu, C.; Lycke, N.; Lynch, L.; Cardell, S.; Lavelle, E. Type II NKT Cell Agonist, Sulfatide, Is an Effective Adjuvant for Oral Heat-Killed Cholera Vaccines. Vaccines 2021, 9, 619. [CrossRef] [PubMed]

337. Dasgupta, S.; Kumar, V. Type II NKT cells: A distinct CD1d-restricted immune regulatory NKT cell subset. Immunogenetics 2016, 68, 665-676. [CrossRef] [PubMed]

338. Nishioka, Y.; Masuda, S.; Tomaru, U.; Ishizu, A. CD1d-Restricted Type II NKT Cells Reactive with Endogenous Hydrophobic Peptides. Front. Immunol. 2018, 9. [CrossRef]

339. Stax, A.M.; Tuengel, J.; Girardi, E.; Kitano, N.; Allan, L.L.; Liu, V.; Zheng, D.; Panenka, W.J.; Guillaume, J.; Wong, C.-H.; et al Autoreactivity to Sulfatide by Human Invariant NKT Cells. J. Immunol. 2017, 199, 97-106. [CrossRef]

340. Roy, K.C.; Maricic, I.; Khurana, A.; Smith, T.R.F.; Halder, R.C.; Kumar, V. Involvement of secretory and endosomal compartments in presentation of an exogenous self-glycolipid to type II NKT cells. J. Immunol. 2008, 180, 2942-2950. [CrossRef] [PubMed]

341. Barral, D.C.; Brenner, M.B. CD1 antigen presentation: How it works. Nat. Rev. Immunol. 2007, 7, 929-941. [CrossRef]

342. De la Salle, H.; Mariotti, S.; Angenieux, C.; Gilleron, M.; Garcia-Alles, L.F.; Malm, D.; Berg, T.; Paoletti, S.; Maître, B.; Mourey, L.; et al. Assistance of microbial glycolipid antigen pro-cessing by CD1e. Science 2005, 310, 1321-1324. [CrossRef]

343. Ichikawa, S.; Sakiyama, H.; Suzuki, G.; Hidari, K.I.; Hirabayashi, Y. Expression cloning of a cDNA for human ceramide glucosyltransferase that catalyzes the first glycosylation step of glycosphingolipid synthesis. Proc. Natl. Acad. Sci. USA 1996, 93, 4638-4643. [CrossRef]

344. Yuan, W.; Qi, X.; Tsang, P.; Kang, S.-J.; Illarionov, P.A.; Besra, G.; Gumperz, J.; Cresswell, P. Saposin B is the dominant saposin that facilitates lipid binding to human CD1d molecules. Proc. Natl. Acad. Sci. USA 2007, 104, 5551-5556. [CrossRef]

345. Zhou, D.; Cantu, C.; Sagiv, Y.; Schrantz, N.; Kulkarni, A.B.; Qi, X.; Mahuran, D.J.; Morales, C.R.; Grabowski, G.A.; Benlagha, K.; et al. Editing of CD1d-Bound Lipid Antigens by Endosomal Lipid Transfer Proteins. Science 2004, 303, 523-527. [CrossRef] [PubMed]

346. Kang, S.-J.; Cresswell, P. Saposins facilitate CD1d-restricted presentation of an exogenous lipid antigen to T cells. Nat. Immunol. 2004, 5, 175-181. [CrossRef] [PubMed]

347. Gerlini, G.; Tun-Kyi, A.; Dudli, C.; Burg, G.; Pimpinelli, N.; Nestle, F.O. Metastatic Melanoma Secreted IL-10 Down-Regulates CD1 Molecules on Dendritic Cells in Metastatic Tumor Lesions. Am. J. Pathol. 2004, 165, 1853-1863. [CrossRef] 
348. Vogt, A.B.; Kropshofer, H.; Moldenhauer, G.; Hammerling, G.J. Kinetic analysis of peptide loading onto HLA-DR molecules mediated by HLA-DM. Proc. Natl. Acad. Sci. USA 1996, 93, 9724-9729. [CrossRef] [PubMed]

349. Kinjo, Y.; Wu, D.; Kim, G.; Xing, G.-W.; Poles, M.; Ho, D.D.; Tsuji, M.; Kawahara, K.; Wong, C.-H.; Kronenberg, M. Recognition of bacterial glycosphingolipids by natural killer T cells. Nature 2005, 434, 520-525. [CrossRef]

350. Bendelac, A.; Savage, P.B.; Teyton, L. The Biology of NKT Cells. Annu. Rev. Immunol. 2007, 25, 297-336. [CrossRef]

351. Michel, M.L.; Keller, A.C.; Paget, C.; Fujio, M.; Trottein, F.; Savage, P.B.; Wong, C.H.; Schneider, E. Identification of an IL-17producing NK1.1(neg) iNKT cell population involved in airway neutrophilia. J. Exp. Med. 2007, 204, 995-1001. [CrossRef] [PubMed]

352. Coquet, J.M.; Kyparissoudis, K.; Pellicci, D.; Besra, G.; Berzins, S.P.; Smyth, M.J.; Godfrey, D.I. IL-21 is produced by NKT cells and modulates NKT cell activation and cytokine production. J. Immunol. 2007, 178, 2827-2834. [CrossRef]

353. Beckman, E.M.; Porcelli, S.A.; Morita, C.T.; Behar, S.; Furlong, S.T.; Brenner, M.B. Recognition of a lipid antigen by CD1-restricted $\alpha \beta+$ T cells. Nature 1994, 372, 691-694. [CrossRef]

354. Kawano, T.; Cui, J.; Koezuka, Y.; Toura, I.; Kaneko, Y.; Motoki, K.; Ueno, H.; Nakagawa, R.; Sato, H.; Kondo, E.; et al. CD1dRestricted and TCR-Mediated Activation of V $\alpha 14$ NKT Cells by Glycosylceramides. Science 1997, 278, 1626-1629. [CrossRef] [PubMed]

355. Nieuwenhuis, E.E.; Matsumoto, T.; Exley, M.; Schleipman, R.A.; Glickman, J.; Bailey, D.T.; Corazza, N.; Colgan, S.P.; Onderdonk, A.B.; Blumberg, R.S. CD1d-dependent macrophage-mediated clearance of Pseudomonas aeruginosa from lung. Nat. Med. 2002, 8, 588-593. [CrossRef] [PubMed]

356. Hansen, D.S.; Siomos, M.-A.; Buckingham, L.; Scalzo, A.A.; Schofield, L. Regulation of Murine Cerebral Malaria Pathogenesis by CD1d-Restricted NKT Cells and the Natural Killer Complex. Immunity 2003, 18, 391-402. [CrossRef]

357. Kawakami, K.; Kinjo, Y.; Uezu, K.; Yara, S.; Miyagi, K.; Koguchi, Y.; Nakayama, T.; Taniguchi, M.; Saito, A. Monocyte chemoattractant protein-1-dependent increase of V alpha 14 NKT cells in lungs and their roles in Th1 response and host defense in cryptococcal infection. J. Immunol. 2001, 167, 6525-6532. [CrossRef]

358. Hong, S.; Wilson, M.T.; Serizawa, I.; Wu, L.; Singh, N.; Naidenko, O.V.; Miura, T.; Haba, T.; Scherer, D.C.; Wei, J.; et al. The natural killer T-cell ligand $\alpha$-galactosylceramide prevents autoimmune diabetes in non-obese diabetic mice. Nat. Med. 2001, 7, $1052-1056$. [CrossRef]

359. Iba, M.; Kim, C.; Sallin, M.; Kwon, S.; Verma, A.; Overk, C.; Rissman, R.A.; Sen, R.; Sen, J.M.; Masliah, E. Neuroinflammation is associated with infiltration of T cells in Lewy body disease and $\alpha$-synuclein transgenic models. J. Neuroinflammation 2020, 17, 1-14. [CrossRef] [PubMed]

360. Larsson, L.C.; Anderson, P.; Widner, H.; Korsgrent, O. Enhanced survival of porcine neural xenografts in mice lacking CD1d1, but no effect of NK1.1 depletion. Cell Transplant. 2001, 10, 295-304. [CrossRef] [PubMed]

361. Karlsson, A.; Dahlgren, C. Assembly and Activation of the Neutrophil NADPH Oxidase in Granule Membranes. Antioxidants Redox Signal. 2002, 4, 49-60. [CrossRef]

362. Kopprasch, S.; Pietzsch, J.; Graessler, J. Validation of different chemilumigenic substrates for detecting extracellular generation of reactive oxygen species by phagocytes and endothelial cells. Luminescence 2003, 18, 268-273. [CrossRef]

363. Duval, C.; Cantero, A.V.; Auge, N.; Mabile, L.; Thiers, J.C.; Negre-Salvayre, A.; Salvayre, R. Proliferation and wound healing of vascular cells trigger the generation of extracellular reactive oxygen species and LDL oxidation. Free. Radic. Biol. Med. 2003, 35 , 1589-1598. [CrossRef]

364. Harris, G.K.; Shi, X. Signaling by carcinogenic metals and metal-induced reactive oxygen species. Mutat. Res. Mol. Mech. Mutagen. 2003, 533, 183-200. [CrossRef] [PubMed]

365. Rao, N.A. Role of oxygen free radicals in retinal damage associated with experimental uveitis. Trans. Am. Ophthalmol. Soc. 1990, 88, 797-850.

366. Winkler, B.S.; Boulton, M.E.; Gottsch, J.D.; Sternberg, P. Oxidative damage and age-related macular degeneration. Mol. Vis. 1999, $5,32$.

367. Cai, J.; Nelson, K.C.; Wu, M.; Sternberg, P., Jr.; Jones, D.P. Oxidative damage and protection of the RPE. Prog. Retin. Eye Res. 2000, 19, 205-221. [CrossRef]

368. Truscott, R.J. Age-Related Nuclear Cataract: A Lens Transport Problem. Ophthalmic Res. 2000, 32, 185-194. [CrossRef]

369. Yoshida, Y.; Umeno, A.; Shichiri, M. Lipid peroxidation biomarkers for evaluating oxidative stress and assessing antioxidant capacity in vivo. J. Clin. Biochem. Nutr. 2013, 52,9-16. [CrossRef]

370. Farooqui, T.; Farooqui, A.A. Lipid-Mediated Oxidative Stress and Inflammation in the Pathogenesis of Parkinson's Disease. Park. Dis. 2011, 2011, 1-9. [CrossRef] [PubMed]

371. Trappe, T.A.; Liu, S.Z. Effects of prostaglandins and COX-inhibiting drugs on skeletal muscle adaptations to exercise. J. Appl. Physiol. 2013, 115, 909-919. [CrossRef]

372. Birch, E.E.; Garfield, S.; Hoffman, D.R.; Uauy, R.; Birch, D.G. A randomized controlled trial of early dietary supply of long-chain polyunsaturated fatty acids and mental development in term infants. Dev. Med. Child Neurol. 2000, 42, 174-181. [CrossRef] [PubMed]

373. Higgins, A.J.; Lees, P. The acute inflammatory process, arachidonic acid metabolism and the mode of action of anti-inflammatory drugs. Equine Veter J. 1984, 16, 163-175. [CrossRef] [PubMed] 
374. Farooqui, A.A.; Horrocks, L.A.; Farooqui, T. Glycerophospholipids in brain: Their metabolism, incorporation into membranes, functions, and involvement in neurological disorders. Chem. Phys. Lipids 2000, 106, 1-29. [CrossRef]

375. Smink, W.; Gerrits, W.J.; Gloaguen, M.; Ruiter, A.; van Baal, J. Linoleic and $\alpha$-linolenic acid as precursor and inhibitor for the synthesis of long-chain polyunsaturated fatty acids in liver and brain of growing pigs. Animal 2012, 6, 262-270. [CrossRef]

376. Wang, Y.; Plastina, P.; Vincken, J.-P.; Jansen, R.; Balvers, M.; Klooster, J.P.T.; Gruppen, H.; Witkamp, R.; Meijerink, J. NDocosahexaenoyl Dopamine, an Endocannabinoid-like Conjugate of Dopamine and the n-3 Fatty Acid Docosahexaenoic Acid, Attenuates Lipopolysaccharide-Induced Activation of Microglia and Macrophages via COX-2. ACS Chem. Neurosci. 2016, 8, 548-557. [CrossRef]

377. Branchi, I.; D'Andrea, I.; Armida, M.; Carnevale, D.; Ajmone-Cat, M.A.; Pèzzola, A.; Potenza, R.L.; Morgese, M.G.; Cassano, T.; Minghetti, L.; et al. Striatal 6-OHDA lesion in mice: Investigating early neurochemical changes underlying Parkinson's disease. Behav. Brain Res. 2010, 208, 137-143. [CrossRef]

378. Dudek, J. Role of Cardiolipin in Mitochondrial Signaling Pathways. Front. Cell Dev. Biol. 2017, 5, 90. [CrossRef]

379. Paradies, G.; Paradies, V.; Ruggiero, F.M.; Petrosillo, G. Oxidative stress, cardiolipin and mitochondrial dysfunction in nonalcoholic fatty liver disease. World J. Gastroenterol. 2014, 20, 14205-14218. [CrossRef] [PubMed]

380. Pope, S.; Land, J.M.; Heales, S.J. Oxidative stress and mitochondrial dysfunction in neurodegeneration; cardiolipin a critical target? Biochim. Biophys. Acta (BBA)—Bioenerg. 2008, 1777, 794-799. [CrossRef]

381. Carta, G.; Murru, E.; Banni, S.; Manca, C. Palmitic Acid: Physiological Role, Metabolism and Nutritional Implications. Front. Physiol. 2017, 8, 902. [CrossRef]

382. Ostrander, D.B.; Sparagna, G.C.; Amoscato, A.A.; McMillin, J.B.; Dowhan, W. Decreased Cardiolipin Synthesis Corresponds with Cytochromec Release in Palmitate-induced Cardiomyocyte Apoptosis. J. Biol. Chem. 2001, 276, 38061-38067. [CrossRef] [PubMed]

383. Korbecki, J.; Bajdak-Rusinek, K. The effect of palmitic acid on inflammatory response in macrophages: An overview of molecular mechanisms. Agents Actions 2019, 68, 915-932. [CrossRef] [PubMed]

384. Robotta, M.; Gerding, H.R.; Vogel, A.; Hauser, K.; Schildknecht, S.; Karreman, C.; Leist, M.; Subramaniam, V.; Drescher, M. Alpha-Synuclein Binds to the Inner Membrane of Mitochondria in an $\alpha$-Helical Conformation. ChemBioChem 2014, 15, 2499-2502. [CrossRef] [PubMed]

385. Ryan, T.; Bamm, V.V.; Stykel, M.; Coackley, C.L.; Humphries, K.M.; Jamieson-Williams, R.; Ambasudhan, R.; Mosser, D.D.; Lipton, S.A.; Harauz, G.; et al. Cardiolipin exposure on the outer mitochondrial membrane modulates $\alpha$-synuclein. Nat. Commun. 2018, 9 , 1-17. [CrossRef]

386. Gao, G.; Wang, Z.; Lu, L.; Duan, C.; Wang, X.; Yang, H. Morphological analysis of mitochondria for evaluating the toxicity of $\alpha$-synuclein in transgenic mice and isolated preparations by atomic force microscopy. Biomed. Pharmacother. 2017, 96, 1380-1388. [CrossRef]

387. Clementi, M.E.; Lazzarino, G.; Sampaolese, B.; Brancato, A.; Tringali, G. DHA protects PC12 cells against oxidative stress and apoptotic signals through the activation of the NFE2L2/HO-1 axis. Int. J. Mol. Med. 2019, 43, 2523-2531. [CrossRef] [PubMed]

388. Schulze-Osthoff, K.; Beyaert, R.; Vandevoorde, V.; Haegeman, G.; Fiers, W. Depletion of the mitochondrial electron transport abrogates the cytotoxic and gene-inductive effects of TNF. EMBO J. 1993, 12, 3095-3104. [CrossRef]

389. Corda, S.; LaPlace, C.; Vicaut, E.; Duranteau, J. Rapid Reactive Oxygen Species Production by Mitochondria in Endothelial Cells Exposed to Tumor Necrosis Factor- $\alpha$ Is Mediated by Ceramide. Am. J. Respir. Cell Mol. Biol. 2001, 24, 762-768. [CrossRef]

390. Mendes, A.F.; Caramona, M.M.; Carvalho, A.P.; Lopes, M.C. Hydrogen peroxide mediates interleukin-1 $\beta$-induced AP-1 activation in articular chondrocytes: Implications for the regulation of iNOS expression. Cell Biol. Toxicol. 2003, 19, 203-214. [CrossRef]

391. Brigelius-Flohé, R.; Banning, A.; Kny, M.; Böl, G.-F. Redox events in interleukin-1 signaling. Arch. Biochem. Biophys. 2004, 423, 66-73. [CrossRef]

392. Hwang, Y.S.; Jeong, M.; Park, J.S.; Kim, M.H.; Lee, D.B.; Shin, B.A.; Mukaida, N.; Ellis, L.M.; Kim, H.R.; Ahn, B.W.; et al. Interleukin-1 $\beta$ stimulates IL-8 expression through MAP kinase and ROS signaling in human gastric carcinoma cells. Oncogene 2004, 23, 6603-6611. [CrossRef]

393. Kaur, J.; Turner, R.B.; Dhaunsi, G.S. Interleukin-1 and Nitric Oxide Increase NADPH Oxidase Activity in Human Coronary Artery Smooth Muscle Cells. Med. Princ. Pr. 2003, 13, 26-29. [CrossRef] [PubMed]

394. Pearl-Yafe, M.; Halperin, D.; Halevy, A.; Kalir, H.; Bielorai, B.; Fabian, I. An oxidative mechanism of interferon induced priming of the Fas pathway in Fanconi anemia cells. Biochem. Pharmacol. 2003, 65, 833-842. [CrossRef]

395. Watanabe, Y.; Suzuki, O.; Haruyama, T.; Akaike, T. Interferon-gamma induces reactive oxygen species and endoplasmic reticulum stress at the hepatic apoptosis. J. Cell. Biochem. 2003, 89, 244-253. [CrossRef]

396. Lawrence, T. The Nuclear Factor NF-kappa B Pathway in Inflammation. Cold Spring Harb. Perspect. Biol. 2009,1, a001651. [CrossRef]

397. Blesa, J.; Trigo-Damas, I.; Quiroga-Varela, A.; Jackson-Lewis, V.R. Oxidative stress and Parkinson's disease. Front. Neuroanat. 2015, 9, 91. [CrossRef] [PubMed]

398. Ryu, J.K.; Shin, W.H.; Kim, J.; Joe, E.H.; Lee, Y.B.; Cho, K.G.; Oh, Y.J.; Kim, S.U.; Jin, B.K. Trisialoganglioside GT1b induces in vivo degeneration of nigral dopaminergic neurons: Role of microglia. Glia 2002, 38, 15-23. [CrossRef] [PubMed]

399. Erard, F.; Wild, M.T.; Garcia-Sanz, J.A.; le Gros, G. Switch of CD8 T Cells to Noncytolytic CD8-CD4-Cells that Make T H 2 Cytokines and Help B Cells. Science 1993, 260, 1802-1805. [CrossRef] [PubMed] 
400. Diehl, S.A.; Schmidlin, H.; Nagasawa, M.; Blom, B.; Spits, H. IL-6 Triggers IL-21 production by human CD4 + T cells to drive STAT3-dependent plasma cell differentiation in B cells. Immunol. Cell Biol. 2012, 90, 802-811. [CrossRef]

401. Eisenbarth, S.C.; Baumjohann, D.; Craft, J.; Fazilleau, N.; Ma, C.S.; Tangye, S.G.; Vinuesa, C.G.; Linterman, M.A. CD4+ T cells that help B cells-A proposal for uniform nomenclature. Trends Immunol. 2021, 42, 658-669. [CrossRef] [PubMed]

402. Hohlfeld, R.; Dornmair, K.; Meinl, E.; Wekerle, H. The search for the target antigens of multiple sclerosis, part 2: CD8+ T cells, B cells, and antibodies in the focus of reverse-translational research. Lancet Neurol. 2015, 15, 317-331. [CrossRef]

403. Karsten, C.M.; Pandey, M.K.; Figge, J.; Kilchenstein, R.; Taylor, P.R.; Rosas, M.; McDonald, J.U.; Orr, S.J.; Berger, M.; Petzold, D.; et al. Anti-inflammatory activity of IgG1 mediated by Fc galactosylation and association of Fc $\gamma$ RIIB and dectin-1. Nat. Med. 2012, 18, 1401-1406. [CrossRef]

404. Pandey, M.K. Molecular Basis for Downregulation of C5a-Mediated Inflammation by IgG1 Immune Complexes in Allergy and Asthma. Curr. Allergy Asthma Rep. 2013, 13, 596-606. [CrossRef] [PubMed]

405. Scott, K.M.; Kouli, A.; Yeoh, S.L.; Clatworthy, M.R.; Williams-Gray, C.H. A Systematic Review and Meta-Analysis of Alpha Synuclein Auto-Antibodies in Parkinson's Disease. Front. Neurol. 2018, 9, 815. [CrossRef]

406. Smith, L.M.; Schiess, M.C.; Coffey, M.P.; Klaver, A.C.; Loeffler, D.A. $\alpha$-Synuclein and Anti- $\alpha$-Synuclein Antibodies in Parkinson's Disease, Atypical Parkinson Syndromes, REM Sleep Behavior Disorder, and Healthy Controls. PLoS ONE 2012, 7, e52285. [CrossRef]

407. Papachroni, K.K.; Ninkina, N.; Papapanagiotou, A.; Hadjigeorgiou, G.M.; Xiromerisiou, G.; Papadimitriou, A.; Kalofoutis, A.; Buchman, V.L. Autoantibodies to alpha-synuclein in inherited Parkinson's disease. J. Neurochem. 2006, 101, 749-756. [CrossRef] [PubMed]

408. Akhtar, R.S.; Licata, J.P.; Luk, K.C.; Shaw, L.M.; Trojanowski, J.Q.; Lee, V.M.Y. Measurements of auto-antibodies to $\alpha$-synuclein in the serum and cerebral spinal fluids of patients with Parkinson's disease. J. Neurochem. 2018, 145, 489-503. [CrossRef] [PubMed]

409. Mabbott, N.A.; Alibhai, J.D.; Manson, J. The role of the immune system in prion infection. Handb. Clin. Neurol. 2018, 153, 85-107. [CrossRef] [PubMed]

410. Prigione, A.; Piazza, F.; Brighina, L.; Begni, B.; Galbussera, A.; DiFrancesco, J.C.; Andreoni, S.; Piolti, R.; Ferrarese, C. Alphasynuclein nitration and autophagy response are induced in peripheral blood cells from patients with Parkinson disease. Neurosci. Lett. 2010, 477, 6-10. [CrossRef] [PubMed]

411. Killinger, B.; Labrie, V. The Appendix in Parkinson's Disease: From Vestigial Remnant to Vital Organ? J. Parkinsons Dis. 2019, 9 , S345-S358. [CrossRef]

412. Kim, S.; Jeon, B.S.; Heo, C.; Im, P.S.; Ahn, T.; Seo, J.; Kim, H.; Park, C.H.; Choi, S.H.; Cho, S.; et al. $\alpha$-Synuclein induces apoptosis by altered expression in human peripheral lymphocytes in Parkinson's disease. FASEB J. 2004, 18, 1615-1617. [CrossRef] [PubMed]

413. Grozdanov, V.; Danzer, K.M. Intracellular Alpha-Synuclein and Immune Cell Function. Front. Cell Dev. Biol. $2020,8,562692$. [CrossRef] [PubMed]

414. Gardai, S.J.; Mao, W.; Schuele, B.; Babcock, M.; Schoebel, S.; Lorenzana, C.; Alexander, J.; Kim, S.; Glick, H.; Hilton, K.; et al. Elevated Alpha-Synuclein Impairs Innate Immune Cell Function and Provides a Potential Peripheral Biomarker for Parkinson's Disease. PLoS ONE 2013, 8, e71634. [CrossRef]

415. Magnusen, D.; Nyamajenjere, T.; Rapien, J.; Mckay, M.; Magnusen, A.; Pandey, M. Dendritic cells, CD4+ T cells, and $\alpha$ synuclein triangle fuels neuroinflammation in Parkinson's disease (P3.053). Neurology 2018, 90, P3.053.

416. Pandey, M.K.; Gross, C.; Caballero, M.; McKay, M.A.; Tiwari, D.; Schroeder, L.M.; Gurtler, M.A.; Burrow, T.A. Immune cells encounter with $\alpha$-synuclein fuels neuro-degeneration in Parkinson's disease. J. Immunol. 2016, 196, 51.5.

417. Rajput, A.H.; Rozdilsky, B.; Rajput, A.; Ang, L. Levodopa Efficacy and Pathological Basis of Parkinson Syndrome. Clin. Neuropharmacol. 1990, 13, 553-558. [CrossRef]

418. Stoker, T.B.; Barker, R.A. Recent developments in the treatment of Parkinson's Disease. F1000Research 2020, 9, 862. [CrossRef] [PubMed]

419. Ntetsika, T.; Papathoma, P.-E.; Markaki, I. Novel targeted therapies for Parkinson's disease. Mol. Med. 2021, 27, 1-20. [CrossRef]

420. Marsden, C.D. Problems with long-term levodopa therapy for Parkinson's disease. Clin. Neuropharmacol. 1994, 17 (Suppl. S2), S32-S44. [CrossRef] 